\title{
The Genesis of Arabic Logical Activities: From Syriac Rhetoric and Jewish Hermeneutics to āl-Šăfi' $y$ 's Logical Techniques
}

\author{
Hany Azazy \\ Faculty of Arts, \\ Ain Shams University, \\ Arab Republic of Egypt \\ e-mail: hany.moubarez@art.asu.edu.eg
}

\begin{abstract}
This paper tries to outline a history of development of informal logic in Semitic languages and especially in Arabic. It tries to explain how the first definite formulation of rules of this logic appeared at āl-Šăfi' $y$ 's Risāla, a work on 'uswl all-fiqh or methodology of law. It attempts also to provide new theories and hypotheses about the translation movement in the Arabic and Islamic medieval world.

Keywords: logic, history of logic, legal hermenutics, analogy a fortiori, rhetorics, argumentation, rationality, argumentum a minore ad maius, argumentum a majori ad minus, argumentum of a similitude, methodology of islamic law.
\end{abstract}

\section{Introduction}

He who tries to write a history of the earlier informal Arabic logic has to do two things: (1) reconstruct the historical facts concerning its development, and (2) reformulate it formally ${ }^{1}$ according to that reconstruction. Thus, (1) is a necessary step for (2). In this paper I shall concentrate only on (1) letting (2) for further research. The reason for (1) is due to that most of the accounts we have about it were not intended to be a definite history of the Arabic informal logic but as a complementary history to other branches of study such as history of Islamic law (for example: [82, ch.9] [35] [45, ch.3] [98, ch. 2] $)^{2}$. Furthermore, these accounts disagree with each other ${ }^{3}$ as a result to the paucity of the resources or its fabrications. Thus, the historian of informal logic is compelled to reconstruct history on his own, introducing to this process some hypotheses and theories about the real history and the mental activities such as the translation movement and how texts transform as we shall see in due course.

However, the history of informal Arabic logic could be written through four disciplines: (1) Islamic law and exegesis (of the Scripture), (2) Arabic rhetoric, (3) Arabic and Islamic theology, and (4) Islamic peripatetic, especially its commentaries on Aristotle's Topics and On Rhetoric. In this paper, I shall trace its development only through Arabic and Islamic law, exegesis and rhetoric. That 
is because these disciplines were the first ones to formulate laws and rules of the informal logic in Arabic. This happened in the Arabic translation of Aristotle's On Rhetoric (which was made by Syriacs) on the one hand and in āl-Šāfi'y's Risāla on the other.

\section{A preliminary Outline of the Development of the Logical Activities of the Semitic Peoples}

Up to the middle of the seventh century C.E., and at the eve of the prophet Muhammad's death (d.632), the Semitic peoples had been having three logical traditions: (i) the Hebrew informal logic ${ }^{4}$ which founded in the first millennium by Hillel the Elder and developed into two traditions, one in Palestine ('Aqiva's tradition) thriving in its yešhivahs, and the other in Mesopotamia (Yišm'a'el's tradition) growing in Pumbedton and Sura yešhivahs ${ }^{5}$, in addition to Yemen ${ }^{6}$. The later tradition adopted strongly Hillel's seven rules for interpreting the Bible; i.e. '(1) an argument a fortiori (qal wa-homer), (2) an argument by analogy (gezerah šawah), (3) a generalization (binyan av) based on one instance, [a generalization based on] two instances, (4) universal and particular terms, (5) particular and universal terms, (6) analogy drawn from another passage, and (7) the conclusion drawn from the context' [91, San. 7.11]. The first six of these are (informal) logical rules. Yišm'a'el, however, extended them to be thirteen rules. For the purpose of lucidity, these rules shall be called the Rabbinic sequence and shall be abbreviated as RS from now on, (ii) The second logical informal tradition arose at about the middle of the second century C.E. due to the Syriac polemical theology initiated by the writings of Tatian $(\mathrm{d} .172)^{7}$ and Ephrem of Edessa (d.373) ${ }^{8}$, and (iii) The Syriac formal logic tradition which started off in the sixth century C.E. with translations of Porphyry's Eisagoge and Aristotle's Organon [32, pp. 42; 115 - 116; 122].

The Arabs, up to this period, did not have a logical tradition. This only developed about two centuries later when they had an articulated informal logic thanks to āl-Šăfi' ${ }^{\prime} y$ (d.820). How can this be explained? Answering this question means providing a history of the development of that tradition. However, we have three theories: (1) The first theory stipulates that the rules of the informal logic of āl-Šăfí ${ }^{\prime} y$ are a result of independent evolution of the methodological practices of earlier ancestors' jurists without any foreign influence. Thus, 'having had so many developments that it became mature to a great extent, the method [informal logic] was handed down to āl-Šăfi ' $y$... who analyzed and presented it in an organized way' [11, p.83]. (2) The second theory considers that āl-Šăfi' $y$ borrowed his informal techniques from the Rabbinic traditions via earlier jurists. This theory which was first articulated by Margoliouth [68, pp.73 - 97] and then defended by Schacht [83, p. 13], and followed by many others (for example: [97], who claims that the influence is direct and without mediation, p. 67), is based either on (a) the existing similarity between the two used terms for analogy, i.e. qiyās in Arabic and heqqeš in Hebrew [67, p. 320] [82, p. 99] [83, p. 14], both of them mean literally measurement, or (b) on 'striking parallels with the Talmudic method' [97, p. 60] i.e. the fact that there is the same succession in RS and āl-Šāfi'y's rules. (3) The third theory argues that āl-Šăfi' $y$ borrowed his rules either from (a) the Iraqis who borrowed them from the Babylonian Rabbis [93, pp. 17-20; 23-25], and either (b) Aristotle's prior analytics to the extent that qiyās (definitely analogy not the a fortiori) is a form of Aristotelian syllogism [ibid., pp. 14 16] or (c) from Aristotle's Topics [1].

The first theory cannot be adhered to, because the cultural diversity of the Islamic civilization compelled us to assume the fact of foreign influences on Arabic and Islamic disciplines. Although the second theory seems to be reasonable, there is no strong evidence for it. Concerning its (a), the linguistic and philological analysis alone is not enough for proving the borrowing, especially as the Palestinian Talmud employed the term heqqeš in a way different from how the Babylonians employed it, i.e. the heqqeš in the Palestinian Talmud was an attempt to search for the common element ${ }^{9}$, while heqqeš for the Babylonians (Yišm'a'el's School) was analogy of the judgement as a result to 'the proximity of two terms within a verse' [27, p. 82]. Given that most of Muslim jurists in the earlier period were living in the Arabian Peninsula or Mesopotamia, and that 'In applying qiy $\bar{a} s$ the Kufians seek the element which is common to both the original and the 
assimilated case' [23, p. 209], this theory needs more scrutiny. Concerning part (b) of this theory, we do not find any sequence in āl-Šāfi' 'y's Risāla like the RS one. In Risāla K: $122-125^{10}$, ālŠăfi'y speaks about qiyās mentioning only analogy without any hint to the a fortiori argument. In Risāla K: $179 \mathrm{ff}$., he talks about the general and the particular after mentioning the importance of the Arabic language in understanding the Qur'ān but not as a term in a sequence. In Risāla K:1482 ff., when he mentions the a fortiori followed by analogy, there is no mention after this to the rest of RS. The same criticism of (2-a) can be applied to part (a) of the third theory. Its part (b) is either unacceptable or unreasonable. It is unacceptable because if Triyanta meant ${ }^{11} \mathrm{Ibn}$ āl-Muqaffa"s translation of an incomplete epitome of prior analytics [36, pp. 63 -93] [87, p. 530], we find a great difference in the terminology, Ibn āl-Muqaffa' does not use the term qiyās at all; instead he uses the term 'șan ' $a$ ' for syllogism [36, p. 64] given that Ibn āl-Muqaffa' himself uses the term qiyās for another mode of inference different from syllogism, i.e. analogy ${ }^{12}$. And it is unreasonable because if Triyanta meant the later translation of Prior Analytics by a certain Theodore, then it should be noted that this translation appeared in the ninth century only [88, p. 533], probably after āl-Šăfi'y's death (in 820). If Triyanta tried to reduce āl-Šăfi ‘y’s analogy to Prior Analytics' syllogisms, AbdelRahman tried to reduce āl-Šăfi'y's the a fortiori to Aristotle's Topics. Thus, the (c) of the third theory seems probable especially that Timothy's (d.823) translation of Topics was current (about 782; [42, p. 61]) even in the time before āl-Šăfi' $y$ 's arrival to Baghdad (about 795; [34, p.182]). But the difference in the number of the a fortiori rules in Topics - Aristotle defines seven rules for the $a$ fortiori in his Topics, ii, ch.X, 114b 37 - 115a 2 while in āl-Šăfi'y's Risāla there are only three [(Risāla K: $1483-1485]$ - makes this part of the theory also improbable.

In order to explain the rise of the informal logical tradition in âl-Šăfi' ${ }^{\prime} y$ oeuvre we need: (1) to reconstruct the Islamic legal and exegetical activities after Muhammad's death on the one hand, and (2) to reconstruct also the earlier history of the translation movement in the Islamic civilization on the other hand. Both of these reconstructions will allow us to discuss the rise and development of the informal logical tradition in āl-Šăfi 'y's Risāla and how he was influenced by RS and the Arabic translation of Aristotle's On Rhetoric.

\section{The Islamic Legal and Exegetical Activities After Muḥammad's Death and the Earlier History of the Translation Movement in the Islamic Civilization}

After Muhammed's death and the extension the Arabic empire through many territories, the caliphs faced the problem of judicature between the members of the conquering tribes. In Muhammad's days, believers used to obey his injunctions, but now faced new situation because they had new facts without Muhammad being there. However, these first caliphs appointed many officers and judges who were judging, in addition to the Qur'annic injunctions, according to customs and previous traditions and they were using their own opinions in some cases [47, p. 55]. 'Umar I (d.644) himself supported their using of their opinion ( $\left.r a^{\prime} y\right)$ by using analogy in a famous letter ${ }^{13}$ to اعرف الأشباه / Âbw Mwsā āl-Āšcary: '(1) Know the likes and the similes (2) then measure things أو الأمثال، ثم قس الأمور عند ذلك scholars in the first half of the last century because it was contained 'the most weighty arguments of the defenders of $r a^{\prime} y$, who endeavoured to fabricate for its validity an old tradition, and an authority going back to the earliest time of Islam' [41, pp. 8 - 9] as Goldziher claimed. But after then, other scholars such as Bravmann [31, p. $179 \mathrm{ff}$.] considered it trustworthy because of the identification of $r \bar{a} y$, 'ilm and 'ijtihād in earlier Islam. In fact, as we shall see, both of them are not right; the passage number (1) in which 'Umar I talks about the likes and similes is genuine, till here Bravmann is right, but the second part of the citation (2) where 'Umar I talks about qiyās is not genuine. This can be deduced from the continuation of the letter where we find 'Umar I saying 'and adopt the judgment which is most pleasing to God and most in conformity with justice so far as you can see / ثم اعمد إلى أحبها إلى الله، وأثبهـا بالحق فيما ترى '7 ii, p. 49] [67, p. 312]. this passage is in nearly coincidence with Ibn āl-Muqaffa's criterion for choosing amongst analogies: 
qiyās is a tool for inferring good things, if it led to what is good and known it should be taken, but if it leads to what is bad and denied it should be abandoned; that is because he who uses qiy $\bar{a} s$ is not pursuing only qiyās but the good and known things and what is assigned as justice by its people.

و إنما القياس دليل يستدل به على المحاسن، فإذا كان ما يقود إليه حسناً معروفاً أخذ به، و إذا قاد إلى القبيح

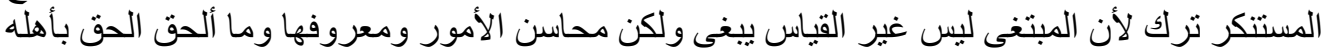

[53, p.317].

Thus, "the defenders of " $r a$ ' $y$ ", as Goldziher said, fabricated the second part of the cited passage (2) to enforce their position.

However, this letter is a keystone for discovering the evolution of the Arabic intellectual movement (translation movement) and the transmission of the Rabbinic logical tradition into the Arabs and Islamic legal system as we shall show.

\section{1. 'Umar I and the Translation Movement}

'Umar I was not illiterate, 'he was reading the books' [61 iii, p. 248] [cf. Also, 20 iv, p. 201]. Moreover, he had always been interesting in the Bible or the ancient religious books ${ }^{14}$ and Jewish narratives $^{15}$, he was even copying the Bible ${ }^{16}$, he also permitted to Tamym āl-Dāry (d.660) to tell religious stories ${ }^{17}$ in the mosque, and let the Jewish Rabbi Ka'b āl-Āḥbār ${ }^{18}$ (d.653) and the scholar most influenced by Jewish traditions, i.e. Ibn 'Abbās (d. 688) ${ }^{19}$, have been the most prominent members of his circle. These facts make us infer that 'Umar I was a man of culture ${ }^{20}$, especially that he was alleged to have had important role in collecting the Qur'ān [61 ii, p. 307] [50 i, p. 166] ${ }^{21}$. Although Muhammad's objection to his reading and copying books ${ }^{22}$, when he became a caliph he made the translation of the Bible more disciplined than it was at Muhammad's time ${ }^{23}$. Thus, we can infer that he established the first translation movement in the Arabic and Islamic civilization from the other Semitic languages into Arabic ${ }^{24}$ as a result to his previous interest in the scripture on the one hand and the need to understanding the Qur'änic hints to the Semitic stories on other hand. The two figures who mainly carried the burden of this movement were the Yemenites Tamym āl-Dāry and Ka'b āl-Āhbār. As the early Muslim society was as yet unfamiliar with organized institutions, story-telling was the first way of translating; hence the translation was oral not written. Thus, 'Umar I gave permission for āl-Dāry to narrate in the mosque, he did so also with $\mathrm{Ka}^{\mathrm{b}} \mathrm{b}^{25}$, and the secretary of this movement was Ibn 'Abbās ${ }^{26}$, and it is not surprise that Ibn 'Abbās' family had the legal guardianship on $\mathrm{Ka}^{6} \mathrm{~b}^{27}$ (he was their mawlā).

But which books were being translated by $\mathrm{Ka}^{\mathrm{a}} \mathrm{b}$ and the others? By answering this question we can at least partly solve the problem of how āl-Šăfi' $y$ was influenced by the Rabbinic logical tradition. The answer also will let us get rid from what I would call it the kaldwnian hypothesis, i.e., that the first Muslims were influenced only by Jewish oral recounts and superstitions ${ }^{28}$, anecdotes [2, p. 1] or at best some isolated sayings of the Rabbis (from the Talmud) [40, pp. 40; 44].

There are two books candidates to have been translated orally by 'Umar's translation movement, i.e. Avot de Rabby Natan or The Fathers according to Rabbi Nathan version A (henceforth referred to as ARNA) and the Toseft' $a$. In this paper I shall concentrate only on ARNA sayings and themes from which many passages were frequently cited by and from 'Umar's secretary of the translation movement (Ibn 'Abbās) and his circle and the adherents of this heritage. If we are able to prove this, it will be easy to prove in addition the transition of the Rabbinic hermeneutical sequence through this book to the early Arabic and Islamic legal traditions, and then to āl-Šăfi' $y$, because $A R N A$ contains that sequence.

To wit: What I shall do would run as the following: Firstly, I shall prove that 'Umar's translators transmitted this book into Arabic through embedding it in some of the prophet's traditions on the one hand, and through its influence on Ibn 'Abbās and his circle on the other. Then, I shall show the influence of the Hebrew logical tradition on Ibn 'Abbās and his circle. 
Secondly, I shall show how most of 'Umar's translators were Yemenites which implies the spread of this book and the Rabbinic logical tradition in Yemen. Thirdly, I shall trace āl-Šăfi ' $y$ 's biography to show how he was indirectly influenced by the Jewish logical tradition and how he amended it and why.

\subsection{The Fathers in Arabic and Islamic Traditions}

We have two versions of The Fathers according to Rabbi Nathan: A and B. Though ARN has a Palestinian origin, both of its versions were known to the Babylonians [80, pp. 16 - 18]. Some scholars even think that version A may have been written in Babylonia [ibid., n. 44]. Because of this, Version A then is our target, and it is thought to have probably been compiled sometime between the seventh and ninth centuries [39, p. xxi]. This would be sufficient for it to be known for $\mathrm{Ka}^{\mathrm{c}} \mathrm{b}$ and the Jews of Yemen. We know that Ka'b āl-Āhbār had books other than the Torah ${ }^{29}$, and he possibly belonged to a Rabbinic tradition ${ }^{30}$, therefore it is probable that ARNA was one of these books. What supports this is the following sentence of a certain exilarch to the Muslims about Ka' $b$ : 'what Ka'b told you about what shall happen is from Israel's prophets and their companions as you

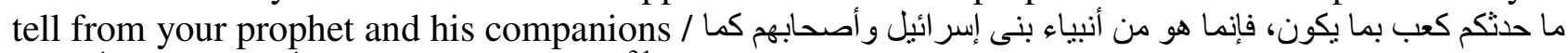
'تحدثون أنتم عن نبيكم و أصحابه not be anything other than the books of the Rabbis, and ARNA is one of these books. Moreover, I shall prove now the influence of ARNA in the fabricated prophets' traditions and in Ibn 'Abbās and his circle opinions.

However, such influence happened on three axes, literal translation, translating the meaning and transmitting themes of ARNA.

But first of all, I have to refer briefly to a methodological problem about the traditions which we are going to depend on (and also to the ones we have quoted so far). Some of these traditions are relating to the sayings of the prophet (Hadyt), and others are relating to the exegetical and legal traditions, especially of Ibn 'Abbās' traditions. On the whole, there are three positions concerning the authenticity of these traditions weather in respect of their content (matn) or ascription ('isna $\bar{d})^{32}$. The first position is extremely skeptical about them. Thus, Schacht thought that 'legal traditions from the Prophet began to appear, approximately, in the second quarter of the second century A.H.' [81, p. 145], and 'traditions from Companions, too, were put into circulation during the whole of the literary period, including the time after Shāfi ì' [82, p. 150]. Wansbrough [96] extended this skepticism to all types of Islamic literature before the third century A.H. [96, pp. 52, 78, 88, 92, 97, 98, 101] $]^{33}$, including Ibn 'Abbās' traditions [ibid., p. 158]. Thus, A. Rippin [78] claimed that we cannot know anything about what happened in the first two centuries of Islam [78, p. 157] $]^{34}$. The second position accepts most traditions after applying philological methods on them ${ }^{35}[29$, pp. $21-$ 23; 72] [71, pp. 35 - 36]. Thus, F. Sezgin believes in the authenticity of the books which were attributed to Ibn 'Abbās [2, p. 17]. However, we cannot accept this second position, the quasi full trust in the traditions is not acceptable, Rippin's analysis of the alleged Ibn 'Abbās books according to methodological and philological considerations seems to be correct ${ }^{36}$. But on the other hand the skepticism of Wansbrough is not acceptable either; we cannot imagine a sudden appearance of the written Islamic literature at the beginnings of the third century A.H. without there being a background for that emergence. This brings us to the third position. This position, on the whole, claims that if we denied the authenticity of the traditions, we could accept that the ideas which lie behind them go back to the earlier Islam. Thus, U. Rubin expresses this position concerning the prophet's sayings as follows: 'But the fact that traditions cannot be dated earlier than 100 A.H. [719 C.E.] does not mean that the ideas reflected in them were not circulated prior to 100 A.H. The lack of documentation does not mean non existence. In other words, the dates of traditions and the dates of exegetical ideas must be considered separately' [79, p. 149]. Schoeler and his school believed also in the possibility to reach to the ideas of the first century A.H. by isnād cum matn analysis ${ }^{37}$. Thus, the sayings of the prophet or of Ibn 'Abbās express on traditions, in the technical meaning of this term ${ }^{38}$, therefore it will not come as a surprise to find that even some of the words of Ibn 
'Abbās' sayings were kept sometimes literally in the minds of their transmitters as I shall show. This position seems plausible and it is our position in this paper, and our reconstruction will prove it. It is the time now to show how ARNA influenced Ibn 'Abbās and his circle.

\subsubsection{The Literal Translation}

I shall display in this subsection only two traditions, the first one is attributed to Ibn 'Abbās and the other to the prophet:

ابن عباس: العلماء يتغايرون' Ibn 'Abbās said student of the Qur'ān are jealous,39

In ARNA we find the same wording: היו עושין מקנאין זה לזה/they [students of the Torah] acted jeaously toward each other. ${ }^{40}$

The following second tradition I divided it into two divisions, the first division does not interest us here, though I shall discuss it in the next subsection of translating by meaning.

'مأfrom Ānas tracing in back to the prophet '(a) Students of the Qur'ān are secretaries of the messengers for the worshipers, (b) unless they make intimacy with ruling powers'. ${ }^{41}$ In $A R N A$, we find: ' ואל תתודע לרשות Dot make intimacy with the ruling powers' (my translation). ${ }^{42}$

However, it should be noted here the following:

1. Both the verbs תתודע and تخالطو are verbs in the increased conjunctional form, and both of them are close semantically, i.e. acquaintance, affinity, knowledge, intimacy and communion.

2. The meaning of the Arabic word a al-sulțān does not signify a king, this was a later development $^{43}$, but it signifies power, authority or sovereign ${ }^{44}$, and this is the same meaning of רשות, hence I translated it in both of the texts as ruling powers. (Nuesner, J. [77], was translating it sometimes as authority, pp. 84-5, and sometimes as sovereign, p. 84)

3. ARNA continues 'for once his name comes to the attention of the ruling powers,' (Goldin's [39] trans. P.62). This sentence has close relationship to the concept of intimacy or $\bar{a} l$-muka $\bar{a} l a t ̧ a^{45}$ in the Arabic tradition.

4. Again, ARNA continues 'they cast their eye upon him and slay him,' (ibid.). This we shall find in another tradition transmitted by Abw-Hurayra, but the translation will be by meaning ${ }^{46}$.

\subsubsection{Translating the Meaning}

The following traditions are translations from ARNA by meaning; I shall first provide the Arabic tradition then its equivalent(s) in ARNA:

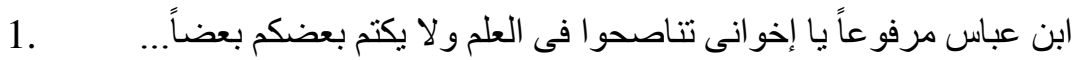

[16 i, p. 207].

Ibn 'Abbās tracing in back to the prophet ' $O$ my brethren, do advice each other in learning and do not conceal it from each other'.

רבי מאיר אומר אם למדת מרב אחד אל תאמר דיי אלא לך אצל חכם ואחר ולמוד תורה [26, p. 16]

Rabbi Meir says, If you have studied the Torah with one master, do not say, 'That is enough,' but go to another sage and study the Torah (Nuesner's [77] trans., p. 33).

והוי מתאבק בעפר רגליהם כיצד בזמן שתלמיד חכם נכנס לעיר אל תאמר איני צריך לו אלא לך אצלו

[26, p. 27] ואל תשרוי מתבר 
AND SIT IN THE VERY DUST AT THEIR FEET: how so? When a scholar comes to the city, say not 'I have no need of him.' On the contrary, go and sit with him (Goldin's [39] trans. With my modification.).

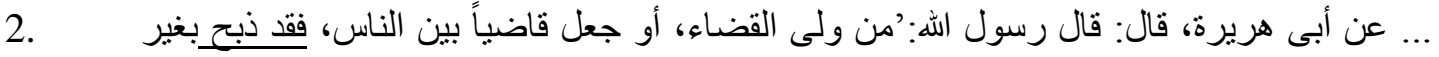
سكين

[17 iii, 1325].

...Abw Hurayra said: The messenger said: 'Whoever become a judge or is appointed as a judge for the people, has been slain without a knife'.

[26, p. 46]

כיון שיצא לו שם ברשות סוף גותגין בו עיניהם והורגים אותו

For once his name comes to the attention of the ruling powers, they cast their eye upon him and slay him (Goldin's [39] trans., p.62).

3.

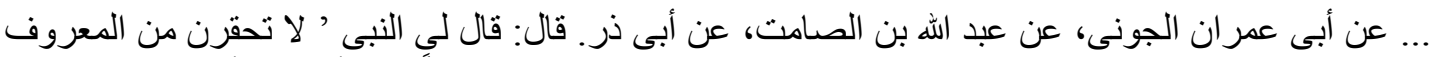

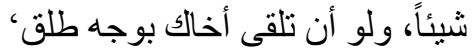

[74 $i, 2626)$

... From Abw imrān āl-Jawny, from Abdallāh b. āl-Şāmit, from Abw Darr. He said: The prophet told me '(a) Do not disdain anything of the good, (b) even if you were to receive your brother with a cheerful face'.

In ARNA we find:

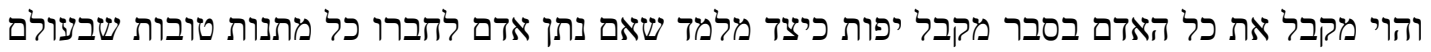

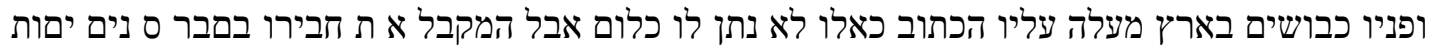

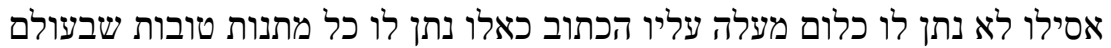

[26, p. 57]

AND RECEIVE ALL MEN WITH A CHEERFUL FACE: what is that? This teaches that if one gives his fellow all the good gifts in the world with a downcast face, Scripture accounts it to him as though he had given him naught. But if he receives his fellow with a cheerful face, even though he gives him naught, Scripture accounts it to him as though he had given him all the good gifts in the world. (Goldin's [39] translation, p.73. with my qualifications).

We should note the following points of the last tradition and its equivalent in ARNA:

a) The Arabic tradition can be divided into two units; (a) and (b). Also the ARNA divides into two units; (a) the text of the Talmudic father's tractate, (b) explanation.

b) The Arabic tradition kept ARNA text; but it brings the explanation first, then the main text of the Talmudic tractate.

c) The second unit of the Arabic tradition is nearly the same of ARNA's first unit, it has even the same words, i.e. מקבל = تلقى = receive. סבר = מלق = cheerful.

d) Abw Imrān āl-Jawny is one of the transmitters on the authority of Abw ālJalad, who was influenced by the Jewish traditions and belonged to Ibn 'Abbās' tradition $^{47}$. 


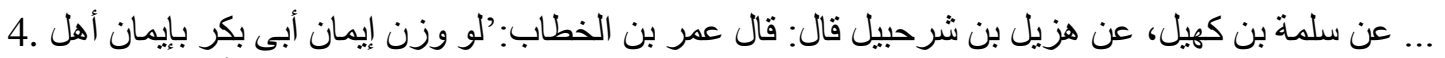

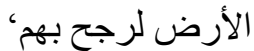

[3i, H35].

... From Salāma b. Kuhayl, from Huzayl b. šuraḥbyl, from Umar b. āl-Katțāb: 'If Abw-Bakr's faith was weight against the faith of the people of the world, his would outweigh them all.

הוא היה אומר אם יהיו כל חכמי ישראל בכף מאזנים ורבי אליעזר בן הורקנום בכף שנייה מכריע את כ26, p. 58 [ליהם

He used to say: if all the sages of Israel were in one scale of the balance and Rabbi Eliezer ben Hyrcanus were in the other scale, he would outweigh them all (Goldin's [39] trans., p. 75).

We should notice here the name of Salāma b. Kuhayl, who transmitted many traditions from Ibn 'Abbās circle ${ }^{48}$, in the Isnād chain. This is an indicator that that tradition was current in the Jewish circle of Ibn 'Abbās.

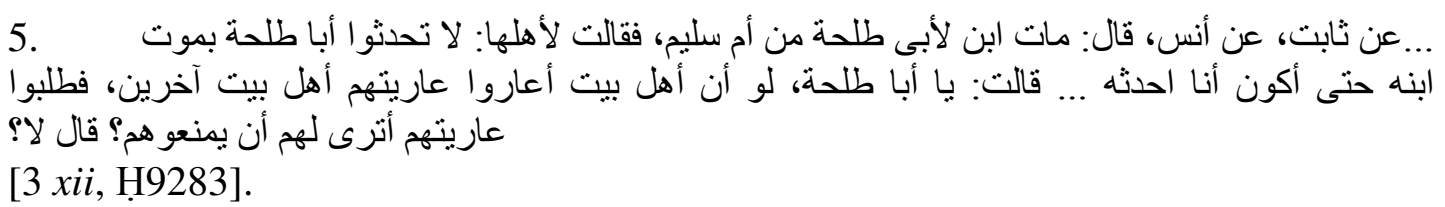

From Tāait that Ānas said: 'A son of Abw Ṭalha by Umm Salym died, then she said to her family: 'Nobody should tell Abw Ṭalha about his son's death except me'... she said to him: 'O Abw Ṭalha, if some people lent others something, and then asked it back, do you think they will be allowed to refuse them?' He said No.'

In $A R N A$, we have the following advice from the mouth of Rabbi Eleazar to Rabban Johanan after the later had lost his son:

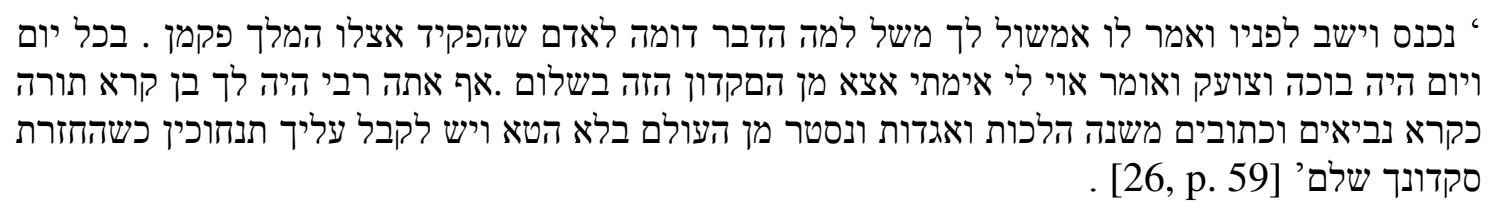

Rabbi Eleazar entered, sat down before him, and said to him:

'I shall tell thee a parable: to what may this be likened? To a man with whom the king deposited some object. Every single day the man would weep and cry out, saying: 'Woe unto me! when shall I be quit of this trust in peace?' Thou too, master, thou hadst a son: he studied the Torah, the Prophets, the Holy Writings, he studied Mišnah, Halakah, 'Aggadah, and he departed from the world without sin. And thou shouldst be comforted when thou hast returned thy trust unimpaired' (Goldin's [39] trans., p. 77).

We should note in the last tradition the name of Tābit āl-Bunany (d.123/741) in the chain of the 'Isnād. He has Yemenite roots [10 iv, p. 342], and Yemen was the principal supply for this early translation movement; he is also reported to have been a storyteller (qāsṣ) [ibid., pp. 346-47].

6. فتنة القبر

[17 ii, Ḥ1074]. 
From 'Abdallā b. 'Amr that the messenger said: If a Muslim dies on Friday or the night of Friday, God will protect him from the grave's suffering.

מת בערב שבת סימן יפה לו.

If one dies on the Sabbath eve, it is a good sign for him (Goldin's [39] trans., p. 107)

We should notice in this tradition the following:

a) The parallelism between the Sabbath eve שבת בערב and the night of Friday ليلة الجمعة

b) The Arabic tradition is attributed to the prophet on the authority of 'Abdallāh b. 'Amr (d.683), who was known for his reading of the Torah books ${ }^{49}$, his acquaintance with $\mathrm{Ka}^{6} \mathrm{~b}^{50}$, his relationship to Ibn 'Abbās' circle ${ }^{51}$ (i.e. the translation movement) and the distinction between the written and oral (Mišnah) Torah ${ }^{52}$.

\subsubsection{Transmitting Themes and the Rabbinic Sequence}

The two most important themes of The Fathers according to Rabbi Nathan are the number seven and the hermeneutical theme as we shall see, but before displaying them I shall display another one as more evidence to translating $A R N A$ and its influence on the Arabic intellectuals.

In $A R N A$, there is a theme in the chapters 1 to 14 about the transition of the Torah from Moses to Joshua to the elders to the Judges to the prophets to the men of great assembly to students of the $\operatorname{Torah}^{53}$, and after chapter 14 we read mainly the sayings of these students. This theme Ka'b transmitted to his colleague Abw āl-Dardā ${ }^{54}$ and the later put it on the tongue of the prophet as '...Scholars are heirs of the prophets / إن العلماء لهم ورثنة الأنبياء' [8 i, p. 105]. A second variant of this tradition is the first clause of Ānas' marfw' report: 'العلماء أمناء الرسلة / الطمله / Scholars are secretaries of the messengers' [16 $i$, p. 219], which we referred to before. However, it should be noted here that in the chain of the transmitters of the first hady there was one of the members of Ibn 'Abbās' Jewish tradition, i.e. 'Ațā' Ibn Aby Muslim āl- Kurāsāny (d.752) [ibid.] $]^{55}$. It should be noted also that Ka‘b was interested $^{56}$ in the Qur'ānic verse which talked about bequeathing the book to the worshipers ${ }^{57}$, and his interest is mentioned in the context of his replying to the Rabbis who blamed him for his conversion to Islam. Thus, he was establishing a new generation of scholars by his contribution in 'Umar's translation movement, following ARNA steps.

In ARNA there is a complete chapter (Goldin's [39] trans. Ch. 37, pp. 152 - 157) about number 7, this I shall call the seven theme. This theme talks about how many things are arranged in seven levels. Thus, 'there are seven created things;' 'seven types of Pharisee;' seven things God created the world with; 'seven heavens;' seven characteristics for the righteous man, clod and wise men... etc..., we find this theme also with Ibn 'Abbās and his circle. Our claim here is in opposite to Goldfeld's opinion that the seven theme (especially in exegesis) only founded at the beginning of the second century A.H. [38, p. 20] by Ibn 'Abbās' disciples via introducing it on the mouth of Ibn Mas'wd [ibid., p. 21]. But as I have referred before, we can assume that many of Ibn 'Abbās' traditions, not necessarily literally, probably go back to him, and Goldfeld believes in this too [ibid., p. 8]. In addition, we have a tradition (see below) that goes back to Ibn 'Abbās himself concerning the number seven, therefore why would Ibn 'Abbās' disciples fabricate a tradition on the authority of Ibn Mas'wd while they have already at their disposal a tradition that goes back to their own master? Moreover, we find also the seven theme in Abdallāh b. 'Amr's traditions, which means it was so spread in early Islam that we can be sure that it were current due to 'Umar's translation movement. However, the tradition which transmits clearly the seven theme is running as follows: On the authority of Sa'yd b. Jubayr, 'Umar asked Ibn 'Abbās, while they were being amongst the immigrants, about determining the time of laylat āl-Qadr, then Ibn 'Abbās replied: 
God is an odd number and loves odd numbers, among his creation he has created seven heavens..., and he has created the earth in seven parts, and he has created the days to be seven in number, he has ordered the circling around the Ka'ba to be seven, throwing the stones to be seven, going and coming to Şafā and Marwā to be seven, he has created the human being from seven and, he has made his daily sustenance from seven.

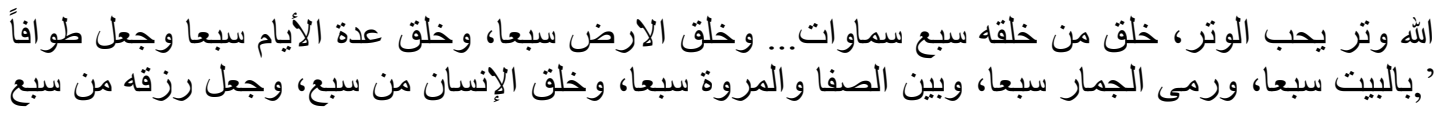

[61 vi, p. 328].

After this, Ibn 'Abbās is going to interpret some Qur'ānic verses according to that [ibid., p. 329]. In the Musnad of 'Abdallāh b. 'Amr as transmitted in āl-Ţabarāny's Mu 'jam we find much more application for that theme (for example: [18 xiii, H14172; H14173; H14195; H14248; H14260; H14299; H14358]). In some of these traditions, we have to notice the names of Ibn 'Abbās' disciples in the chain of Isnād, such as H14173; H14282; H14299 (Mujāhid), H14260 ('Ațā'), Or the name of the Yemenite Wahb b. Munabbih H14358354. Other traditions do not contain Ibn 'Abbās disciples' names such as H14264, this fact confirms the authenticity of all these traditions as an expression of 'Abdallāh b. 'Amr and Ibn 'Abbās' opinion which both of them learnt from ARNA against their fabrications by Ibn 'Abbās' disciples as Goldfeld would have claimed.

The third thesis relates to the interpretation and understanding of scripture. However, ARNA 'is entirely devoted to the 'Aggadah' (Goldin's [39] introduction, p. xviii), it is a book in and about interpretation $^{58}$. By Ka'b's translation of $A R N A$, he also transmitted the importance of interpreting the Qur'ān. Therefore, it is not strange to find Ibn 'Abbās' concentration to have been in exegesis, and to have had a great reputation as interpreter to the Qur'ann (cf. [29, pp. 129 - 131]). Thus, Muqātil Ibn Sulaymān reports on the authority of Ibn Jubayr that Ibn 'Abbās said 'Learn

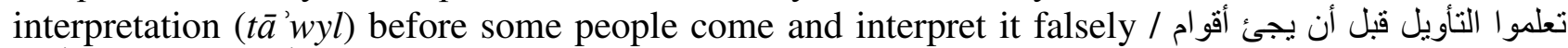
يتأولونه على غير تأويله $A R N A$ on Ibn 'Abbās because he saw that 'God did not send down a book without his wanting that its interpretation should be known / ما أنزل اله كتاباً إلا أحب أن يعلم تأويله ' [ibid.]. This saying is in harmony with ARNA which is an invitation to interpretation. Also we have a fabricated hady $\underline{t}$ on the authority of 'Ikrima that the prophet said ' $\mathrm{O}$ God, give Ibn 'Abbās wisdom and teach him interpretation' $[61 v i, \text { p. 322 }]^{59}$. Thus, Ibn 'Abbās interprets Q3:79 'Be Rabbis,' as be 'wise and jurists,' [19 vi, 7313], and his disciples kept the same interpretation [ibid., 7306 - 7312] as a continuation for the master's tradition. Ibn 'Abbās also was known as 'the Rabbi of this community / ربانى هذه الأمة /61 vi, p. 347]. This identification of interpretation, wisdom and jurisprudence on the one hand, and the interpreter, Rabbi, jurist and scholar on the other hand is a sign of extending the Rabbinic tradition in the Arabic environment by the translation movement and evidence of an oral translation of $A R N A$ which bears all these features. This supports my claim that the transition of informal logic to the Arabs was through ARNA, especially if we recognized that ARNA puts down the rules of interpretation of Scripture in ch. 37, and connects them with the number seven which also was adopted by Ibn 'Abbās.

If we have a look at Ibn 'Abbās' method of interpretation we find it in harmony with these rules. In a recent study on the early interpretation of the Qur'ān, its author defines the method of Ibn 'Abbās (and others) and his school in interpretation as follows: 'Semantic similarity, that is, synonymy $(\bar{a} l-\bar{a} s ̌ b \bar{a} h)$ : In this technique, the exegete makes a semantic analogy between two ayahs through synonymy that exists between them either at the word level or at the thematic level.' [2, p. 157]. This corresponds to RS: 2, 3, 6. The Method of Ibn 'Abbās contains also 'Explaining the generic by the specific,' [ibid., p. 158].This corresponds to RS: 4 - 5. But what about RS:1? Here, we have to return to the history of early Islamic law. Ibn 'Abbās was not only interested in the Qur'ānic narrative's, but also in legal matters in it [38, pp. 15 - 16] [71, p. 287]. Thus, 'lbn 'Abbās, encouraged his students, such as Mujāhid and 'Ikrima, to critically debate Qur'ānic matters and 
provide their exegetical personal opinions, that is, to practise 'ijtihād and 'istinbāt in Qur'änic exegesis' [2, p. 148]. This 'ijtihād (independent reasoning) is nothing other than $R \bar{a}$ 'y (opinion) which prevailed in early Islamic Law [31, pp. $177-178]$. However, this $R \bar{a}$ ' $y$ contains many kinds of reasoning [ibid., p. 193] including of course the a fortiori or RS:1. And according to Bravmann [ibid., pp. 178 - 185] 'Umar I himself was practicing $R \bar{a}$ ' $y$. This brings us back again to 'Umar's letter where he talks about the likes and similes as mental tools to the judge. Thus, 'Umar I himself (and the earlier judges alongside with him) the sponsor of the translation movement seems to have been influenced by $\mathrm{RS}^{60}$.

Accordingly, the Hebrew informal logical tradition was transmitted to the Arabs within their legal activity and hermeneutics or exegesis of the Qur'ān through ARNA thanks to 'Umar's translation movement. And the informal logical rules of that tradition continued especially with Ibn 'Abbās' school and his disciples ${ }^{61}$ until they were delivered to āl-Šăfí 'y who articulated them by the instruments of Aristotele's On Rhetoric. In the next section I shall show how this happened.

\section{The Influence of the Rabbinic Sequence and of Aristotle's On Rhetoric on āl-Šăfí'y}

Ibn 'Abbās' tradition (in law and exegesis) was prominent in two centers, Mecca and Yemen. It concentrated on exegesis, law and translation. In Mecca there were 'Atā' Ibn Abw Rabāh (d. 733), Mujāhid (d. 722), 'Ikrima (d. 723) and Ibn Abw Mulayka (d. 735) [71, p. 287] and others. In Yemen there were Țawws (d.724), Salam āl-Șan'āny (d.770) who were telling on the authority of Țāwws [61 viii, 2592] and Yuswf Ibn Ya'qwb, [ibid., 2595], Hishām Ibn Yuswf ${ }^{62}$ (d. 197) [ibid., 2600] 'Abd āl-Razzāq (d.826) and his father [ibid., 2601]. Also, there were who followed up Ka'b's translations or rather 'Umar's translation movement such as Munabbih's family (Wahb [d. 728] ${ }^{63}$, Hammām (d. $132)^{64}$, Ma'qil, and 'Umar) [ibid., pp. 103 - 107] and Wahb āl-Zzimāry who 'read the books' [ibid., 2579].

The first center was the place where âl-Šăfi' $y$ studied [34, p. 182] and the other where he worked as an officer (including judgment) [4 i, p. 106] [34, p. 182]. Being in these two centers, which kept the Hebraic informal logic tradition, increases the probability of his being influenced by RS. However, in Mecca Ibn 'Abbās' tradition continued up to Sufyān Ibn 'Uyayna [71, p. 289], ālŠāfi'y's teacher [37, p. 43] [34, p. 182]. Ibn 'Uyaynah kept 'Umar's tradition in informal logic, he was one of the chain of the transmitters of 'Umar's letter to Abw Mwsā āl-Ash'ary about how an officer should judge [8 $i, 535]$, which has in it RS: 2, 3, 6. Also, he is reported to have said on the authority of 'Ubaydallāh Ibn Abw Yazyd 'whenever Ibn 'Abbās was being asked about something, then if it was in the Qur' $\bar{a} n$ he told it and if it was not but reported from the messenger of God then he told it, and if it was not in the Qur'ān and was not reported from the messenger of God he كان ابن عباس إذا سئل عن الأمر فإن كان فى القرآن / formulated his own judgment based on his own opinion

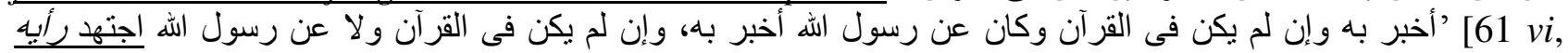
pp.33-34]. The last clause in this tradition 'he formulated his own judgment based on his own opinion lijtahada rā' 'yuhu' is nothing but RS: 1-3; 6. Of course Ibn 'Uyayna transmitted also to ālŠăfi' $y$ the RS: 4-5. But we notice here two things: (a) that āl-Šăfi' $y$ uses the two terms 'general and particular' ('āmm wa kāṣs ) for the RS 4-5 which did not happen in Ibn 'Abbās' tradition and Ka'b's translations, (B) Also he uses the term qiyās for RS 1-3; 6. This can be explained as follows:

RS:4-5, was already articulated with Muqātil by giving them their names: 'in the Qur'ān

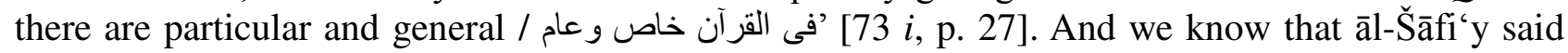
'People are dependent on Muqātil in interpretation' [24 iv, p. 173]. This is an indicator about his borrowing Ibn Muqātil's terminology for general and particular.

âl-Šāfi'y studied also at Medina ${ }^{65}$ which had a linguistic school influenced by Iraqi schools $\left[89\right.$, p. 228] where the term qiyās was being used for analogy $\left[95\right.$, p. 35] ${ }^{66}$. And we know how ālŠăfi'y was interested in the linguistic analysis of the Qur'ān [Risāla K 133-178], and his estimation of āl-Kisā’y (d. 799), one of the champions of grammatical qiy $\bar{a} s^{67}$, is well known ${ }^{68}$. Thus, āl-Šăfi ${ }^{6} \mathrm{y}$ joint this term for RS: $1-3 ; 6$. 
But after his confrontation with Iraqis Jurists ${ }^{69}$, who we do not have any exact formulae for their methods, he felt that he needed to articulate his informal logical techniques (RS: 1-3; 6) which he inherited from Ibn 'Abbās' tradition. It seems that he found he could supersede the Iraqis by doing this, thus he says: "who has no instrument at his disposal, has no permission to say anything in scholarship / فأما من لا آلة فيه فلا يحل له أن يقول فى العلم شيئاً '15 ix, p. 17]. Somehow, when he was in Iraq $^{70}$ he had Aristotle's On Rhetoric, which was already translated from Syriac into Arabic, at his disposal $^{71}$. This is what I shall prove now by analyzing his logical passages in his Risāla and their counterparts in Aristotle's On Rhetoric. And for the convenience, I shall abbreviate the Arabic translation of Aristotle's On Rhetoric as TAR, and when I quote from Badawi's 1979 edition [28] for this translation I shall abbreviate it as TAR B, while quoting from Lyons' 1982a [65] edition for the same translation will be abbreviated as $T A R$ L. Also, I shall abbreviate the translated Aristotle as TA.

Along his writings, āl-Šāfi‘y had only five explicit informal logical rules, three of them for the $a$ fortiori argument, and the remaining two for analogy ${ }^{72}$.

\section{1. $\bar{a} l-\grave{S} \bar{a} f i$ 'y's Three Rules of the a Fortiori}

As we have said above, āl-Šăfi' $y$ had three rules for the a fortiori, these rules are the same as in $T A R$. āl-Šăfi' $y$ even cites them in the same order as in TAR, though he breaks Aristotle's first rule into two parts (Aristotle has only two rules for the a fortiori in his On Rhetoric: [24, 1397b12-25]. However, I shall prove that by citing first TAR's rule then citing its counterpart in āl-Šăfi' $\mathrm{y}^{\text {‘s }}$ Risāla showing how the later articulated his rules through TAR.

$T A R$ 's first rule $=$ The first and second of āl-Šăfi' $y$ 's rules (the argumentum a minore ad maius).

TAR1. ' فإما أن يثبت أنه إن كان الذى هو أقل، كان الذى هو أكثر /E]ither to demonstrate that if it was the less then it would be the more' [TAR B, p. 155; TAR L, p. 149].

āl-Šăfi'y’s first two rules are as follows:

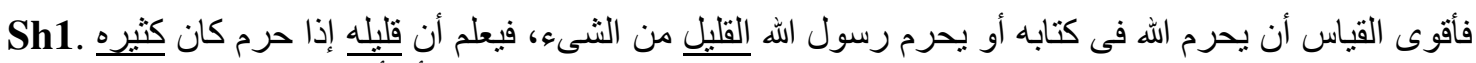
The strongest kind of qiyās is when God, in his book, or God's messenger, forbids a little of something, It is understood that since $\underline{\text { a }}$ little of it is forbidden, then a lot of it would be like a little of it in respect of its being forbidden, or even more so, because of a great quantity is better than a lesser one [Risāla K: 1483; Lowry's [64] trans., p. 153, except the underlined clause].

Sh2. ' وكذللك إذا حُمد على يسير من الطاعة، كان ما هو أكثر منها أولى أن يحمد عليه praiseworthy to be obedient in a small way, then to do so in a greater way would be even more appropriately praise' [Risāla K: 1484; Lowry's [64] trans. p. 153].

We should here notice the following remarks:

1. āl-Šāfi'y has retained some of the very words in TAR's text in his wording, i.e. āqall and ākthar in TAR and katyr, āktar, àl-kațra, qalyl and āl-qilla in āl-Šāfi' $y$ 's wording.

2. āl-Šăfí'y's second rule (id But âl-Šăfi'y as a faithful follower to TAR (as I shall show below) introduced it for both prohibition and permission.

3. In āl-Šāfi ‘y's formulation, there is no mention to subjects and predicates. This is because TAR has none of these terms. That means that āl-Šăfi'y's source was Aristotle's On Rhetoric not Topics as Abdel-Rahman [1] has thought. That also explains why āl-Šăfi'y did not adopt the subjectpredicate scheme. 
4. That the mentioned principle of bi faḍl àl-katra 'ala âl-qilla is an Aristotelian principle; we have two places in which TA speaks about that principle. In [TAR B, p. 32; TAR L, p. 35] he says: ' إن السعة أفض / large amount is better than little one.' Again, in [TAR B, p. 28; TAR L, p. 29] he says: 'because the best is greater than the least.' The synonymy of āl-âfdal, ālsi ' $a$ and $\bar{a} l$-katra on the one hand, and the synonymy of qilla and $\bar{a} l-\bar{a} k \underline{k} a s \underline{s}$ on the other hand can be deduced from a later passage of TAR [TAR B, p. 137; TAR L, p. 133]:

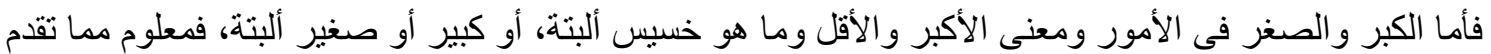

$$
\begin{aligned}
& \text { / Concerning the greatness } \\
& \text { and smallness in things, the meaning of the greatest and the less, and the least, the very }
\end{aligned}
$$

This is why I evaded Lowry's translation of bi faḍl āl-katra 'alā àl-qilla as 'because of the [implied inferential] relationship of the greater to the lesser amount' [64, p.153]. The expression 'the implied inferential relationship' in Lowry's translation is not in āl-Šăfi ‘y's text. It is formal while āl-Šăfí ‘y's principle is rhetorical, religious, ethical and informal as in TAR (we should note here how the Syriac translator translated 'the least' as $\bar{a} l-\bar{a} k \underline{k} a s$ which can mean also the vilest. Thus, there is an ethical connotation in the principle. $)^{74}$

5. However, we find alongside every formulation of this (ethical) principle in TAR a justification for using it from the lesser (good) to the greater (good), thus the full sentence of TAR's first sentence is as follows:

$$
\text { large / أن السعة أفضل من القلة، لأن منفعتها أعظم، فإن التى تكون كثير أ أعظم من التى قليلاً ما تكون }
$$
amount is better than little one because its benefit is much more, i.e. the more is the better [TAR B, p.32; TAR L, p. 35].

The full second sentence is as follows:

$$
\begin{aligned}
& \text { فمن الاضطر ار أن تكون استفادة الخير ات خيراً...فأن [وان] } 75 \text { يستفيد مكان الخير القليل فائدة كثيرة [كبيرة]... } \\
& \text { ف / It necessarily follows that acquisition of the goods is } \\
& \text { good... and the necessity of acquisition of much good instead of a little one... } \\
& \text { because the best is greater than the least [TAR B, pp. 27-28; TAR L, p.29]. }
\end{aligned}
$$

Thus, each citing of the very principle is supplemented or preceded with justification which could be understood as a justification for using the argumentum a minore ad maius in case of permission, and this is what āl-Šăfi' ${ }^{\prime} \mathrm{did}$ as a result of his reading of $T A R$; he put his invalid second rule of his informal logic immediately after his citing the principle.

6. It is clear now that āl-Šăfíy understood that principle literally, which gave him justification to extend the argumentum a minore ad maius to apply on permissions cases too, and in this way he divided TAR.1's rule into two. Of course, if he had read Topics he would not have done this. That means more evidence that āl-Šăfi ‘y's source was TAR.

The third rule is the argumentum a majori ad minus, and we find it also at the same page in which TA speaks about the more and the less topic. Thus, TA says:

This و وذذا الموضع هو أنه إن لم يكن ذلك الأمر للأى هو أحرى أن يكون، فواضح أنه ليس للذى هو أقل أو أنقص، topic is if it was not the case for what is more likely to be, then it is obvious that it cannot be the case for what is less or from what something is missing' [TAR B, p. 155; TAR L, p. 149].

Somewhat later, we read:

$$
\text { فإما أن يُثبت أنه إن كان الذى هو أقل، كان الذى هو أكثر؛ و إما أن يثبت أنه إن لم يكن كذا فلا كذا، فإنما يثبت واحدة }
$$


/ either to demonstrate that if it was the less then it would be the more or to demonstrate that if it was not this then it would not be that, by doing so he is demonstrating one of two: either it is, or it is not because whenever what is more was not the case then it would not be what is less.

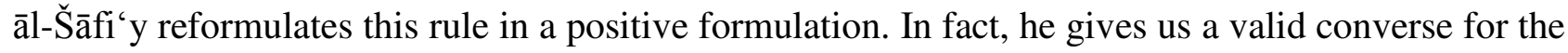
argumentum a majori ad minus as follows:

Sh.3 وكذلك إذا أباح كثير شىء كان الأقل منه أولى أن يكون مباحاً Also, if He permitted a large amount of something, then a lesser amount of it would be even more appropriately permissible' [Risāla $\mathrm{K}$ : 1485; Lowry's [64] trans. P. 153].

As noted above, āl-Šăfi'y's converse formulation is valid. And he seems to have preferred the positive mood of the rule for his purposes.

\section{2. āl-Šăfi 'y’s Two Rules of Analogy}

First of all, Aristotle and TA have two definitions for Analogy or $\pi \alpha \rho \alpha ́ \delta \varepsilon 1 \gamma \mu \alpha$ [TAR B, pp.11; 14-15; TARL, pp. 10, 14]. āl-Šāfi'y also has two definitions for analogy, thus he says: ' ومو افقته [القياس] تكون و he says in another passage: 'و القياس من وجهين qiyās [analogy] has two aspects' [Risāla K: 1334]. Also, we can easily recognize that the content of TAR's two definitions is the same as āl-Šăfi' $y$ 's two definitions.

$T A R$ introduces the first definition of $\pi \alpha \rho \alpha ́ \delta \varepsilon 1 \gamma \mu \alpha$ as following:

TAR.3 أما البر هان... فإنه... كالجزء إلى الجزء و الثبيه إلى الثبيه إذا كانا جميعاً يمكنان تحت ذلك الجنس بعينه concerning paradeigma... it is ... like part to part, like similar to similar, on the condition that both of them could be fallen under the very same genus and that not one of them is an example for the other [TAR $\mathrm{B}, \mathrm{pp}$. 14-15; TAR L, p. 14].

We should notice here that the word 'yumkinnān' can be read as 'could be' or 'to fall under,' i.e 'yakmunnān'. I put both readings in the translation until the text to be understandable. I think that $\bar{a}$ l-Šăfi' $y$ also read both readings as it is clear from his wording of this rule below. However, the meaning of TAR's rule is:

1. $\pi \alpha \rho \alpha ́ \delta \varepsilon \imath \gamma \mu \alpha$ is reasoning from part to part, and from like to like.

2. This happens when (a) The similar things could be fallen under the same genus or meaning, and (b) there is obscurity about their similarity. follows:

Accordingly; we have āl-Šăfi' ${ }^{\prime} y$ 's definition of analogy which is dependent on the TAR as

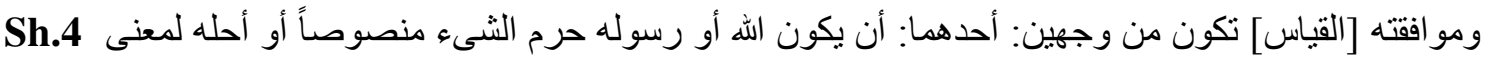

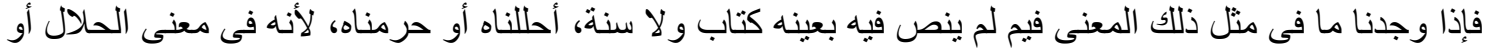
الحرام / its conformity [i.e. qiyās] is to be based on two aspects: the first of them is that God or His messenger have either forbidden a certain thing by a text or permitted it by a meaning. If we find such a meaning in something neither the book nor a sunna has a text about it itself, then we shall permit or prohibit it, because it is in such a meaning of permission or prohibition [Risāla K: 123-24]. 
Khadurri [62, p. 79] and Lowry [64, pp. 149-50] translated the word ma'nā as reason. But this misses the point. Firstly, the exact English equivalent of the word ma' $n \bar{a}$ is meaning not reason. Secondly, āl-Šăfi'y's intention is to search for a meaning not a reason, this is clear from the adjective 'such' in 'if we find such.' Thirdly, if we agreed that he was indirectly influenced by $R S$, it would naturally be that he intended a meaning not a reason. That is because $R S: 3$ is related to searching for genus, a common meaning, or binyan $a v$ (establishing a principle) which is equivalent to the Arabic binā' aṣl. âl-Šăfi'y himself used the word ' أصل / principle or element' in another wording for his rule: 'و القياس من وجهين: أحدهما أن يكون الثىء فى معنى الأصل / Qiyās has two aspects; the first one of them is that the thing has the same meaning of the original thing' [Risāla K: 1334]. ${ }^{77}$

W. Hallaq [45] considered this rule as ratio legis, i.e. 'If the new case has the same ratio legis (ma'nā, lit. meaning) as that given to the parallel textual case, the ruling in the text must be transferred to the new case' [ibid., p.23]. Therefore, a jurist has to search for 'the 'purpose of a statute' [99, p. 310] according to the ratio legis. But āl-Šăfi' $y$ did not mean that ${ }^{78}$, what he meant is that searching for a meaning covers both the known and the unknown cases. What confirms this is the example which āl-Šāfi' ${ }^{\prime} y$ gives for his Sh.4.:

since the child is [an issue] of the father, he [the father] is under an obligation to provide for the child's support while [the child] is unable to do that for himself. So I hold by analogical deduction when the father becomes incapable of providing for himself by his earnings-or from what he owns-then it is an obligation on his children to support him by paying for his expenses and clothing. Since the child is from the father, he [the child] should not cause him from whom he comes to lose anything, just as the child should not lose anything belonging to his children, because the child is from the father. So the forefathers, even if they are distant, and the children, even if they are remote descendants, fall into this category [Risāla M, p. 310. My italics].

Here what âl-Shafi'i calls 'fall into this category' is nothing but the meaning, not the purpose, of 'incapability of providing for himself' which both the father and the child fall under it. Thus, âlŠăfi'y is building a principle or genus or binyan $a v$.

The other TAR definition of $\pi \alpha \rho \alpha ́ \delta \varepsilon 1 \gamma \mu \alpha$ is as follows:

TAR.4. 'فالنحو الذى يكون بإنبات أن هذا فى شيئين متشابهين... هو... برهان The way of demonstrating that this is in two like things is paradeigma' [TAR B, p. 11; TAR L, p. 10].

With the helping of the auxiliary 'could' of the first definition (as a result of āl-Šăfi 'y's reading of يمكنان), which means that a thing may have many likes, āl-Šāfi'y gives his other definition.

Sh. 5. أو نجد الثىء يشبه الثىء منه و الثىء من غيره، و لانجد شيئًا أقرب به شبهاً من أحدهما، فنلحقه بأولى الثياء الأشياء شبهاً به nothing closer to it in resemblance than one of them, then we should relate it to the most closer to it in resemblance [Risāla $\mathrm{K}: 125]$.

We should note here that this definition contains the term $\check{s} a b a h$, which I translated as resemblance and its derivatives, so also TAR contains the term mutashäbih, one of the derivatives of the term šabah.

This rule has another variant which connects it with the previous rule. āl-Šăfí' $y$ says that the resemblance between two things is at the surface [Risāla $\mathrm{K}: 118 ; 119 ; 125]$, but in his variant rule he introduces the resemblance as if it is in meaning. Thus, he says about resolving contradictory analogies:

$$
\text { بأن تنظر إلى النازلة، فإن كانت تنبه أحد الأصلين فى معنى والآخر فى اثثين، صرفت إلى الذى أشبهته فى }
$$


/ you have to look at the case, if it resembles one of the two known cases in a meaning but resembles the other known in two meanings, then you should relate it to the one which resembles it in two meanings not the one which it resembles in one meaning [15 ix, p. 80].

Lowry considered this as a confusion between Sh. 4 and Sh.5 [64, p. 151, n. 134]. But it seems to be a result of the influence of $T A R$ and $R S: 2-3$ on āl-Šăfi ' $y$.

Also, our previous critique of Hallaq's reading to Sh.4 applies on his reading to Sh.5 where he considers Sh.5 as argument of a similitude [46, p. 23], but the argumentum of a similitude is 'concerning the purposes of the 'lawgiver" [99, p. 313] while āl-Šăfi' $y$ 's intention is meaning ${ }^{79}$.

\section{5. āl-Šāfi‘y’s Argumentative Rationality}

Even if we accept the above reconstruction, there might still be doubts concerning the influence of $T A R$ upon āl-Šăfi'y's logic. One might argue that the resemblance of words and the logical structure of the rules do not provide inclusive evidence. However, āl-Šāfi' ${ }^{\prime} \mathrm{y}$ did not only articulate $R S$ by TAR but he even borrowed from the later a theory of argumentative rationality. To prove this, I shall first reconstruct TA's theory of argumentative rationality in TAR, and after this I shall reconstruct allŠăfi'y’s theory.

\subsection{The Theory of Argumentative Rationality in the Arabic Translation of Aristotle's On Rhetoric}

According to TA humans have several modes of speech. These modes lead to truthfulness or $\bar{a} l$ taṣdīq, or as TA says: 'فكل الناس...يستعملون الفصص وتقليد الكلام والاعتداد [الاعتذار] و الثكاية فيصدقون All humans are using investigation, speak according to habit, trust [apology], and complaint to consider truthful' [TRA B, p. 4; TRA L, p. 1]. Also, there are two kinds of art and therefore truthfulness or $\bar{a} l$ tas dīq ${ }^{80}$ in respect of their aim; the aim of the first one is that if / إذا المتكلم تكلم] if the speaker spoke [without justice], then we would refute him' [TAR B, p. 8; TAR L, p. 6]. The art which deals with this kind of truthfulness is dialectics or âl-dyaliqqtqya [ibid.]. Thus, this art has dialectical truthfulness. The other aim is ' أن تعرف المقنعات فى كل أمر من الأمور to recognize the persuasive things in every matter' [TAR B, p. 8; TAR L, p. 6]. The art which deals with this kind of truthfulness is Rhetoric or $\bar{a} l$-rïitüuria [ibid.]. Thus, this art has rhetorical or persuasive truthfulness. This last kind of truthfulness is divided into two types: the first one is artificial and the other is nonartificial, فأما التصديقات فمنها بصناعة ومنها بغير صناعة / the truthful things are either artificial or nonartificial' [TAR B, p. 9; TAR L, p. 7]. The non-artificial truthful things are 'ليست تكون بحيلة مناعة / without our interference' [TAR B, p. 9; TAR L, p. 7]. TA defines five kinds of the non-artificial things; these are 'السنن، و الثهود، و العقد، و العذاب، و الأيمان Sunan (customs or laws), testimony, contract, punishment and oaths' [TAR B, p. 71; TAR L, p. 73].

Artificial truthfulness may be reached by demonstration: و و التصديق إنما يكون بالتثبيت truthfulness have to be by demonstration' [TAR B, p. 6; TAR L, p.4 $]^{81}$. There are two kinds of demonstration in every Art, in dialects there are consideration or ' $i{ }^{\prime} t i b \bar{a} r^{82}$ and saljasa ${ }^{83}$; their counterparts in rhetoric are proof or paradeigma or burhān ${ }^{84}$ and thinking or tafkyr ${ }^{85}$ respectively.

In addition to the two kinds of demonstration there are also pseudo-consideration and pseudo saljasa in dialectics, pseudo-proof and pseudo-thinking in rhetoric ${ }^{86}$. Most rhetorical demonstrations are proofs, but the most powerful are thinkings or tafkyrāt ${ }^{87}$. The premises of thinking are either truths or signs ${ }^{88}$, and the latter is either mappings or signs ${ }^{89}$. We should note here the following: (1) the obscureness of TA about Analytics, (2) that Aristotle's Theory of argumentative rationality has been modified.

Concerning the first point, the (ancient) reader of TAR either believes (a) that there is nothing new in Analytics, or (b) he may understand that On Rhetoric contains Analytics. 
Concerning (a); TA says after talking about the ways of demonstration in dialectics and rhetoric ' و وهذا بيْن واضح فى كتاب أنولوطيقى / this is obvious and clear in the Analytics' [TAR B, p. 11; TAR L, p.10] without any more clarification. And he says after talking about the first kind of the

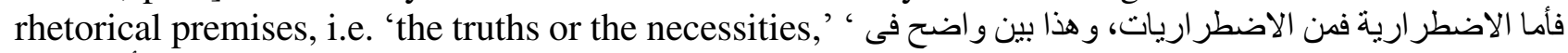
/ The necessary premise is from the necessities, and this obvious and clear in Analytics' [TAR B, p. 13; TAR L, p. 12] without any more clarification too. Again, after talking about the true, mapping (rāsim) and sign, he says 'أما كنه البيان وحقيقته ففى أنولوطيقى / but the essence of the account and its truth is in Analytics' [TAR B, p.14; TAR L, pp. 13 - 14]. This clause does not mean that there would be something different in Analytics, this is because before it directly TA said

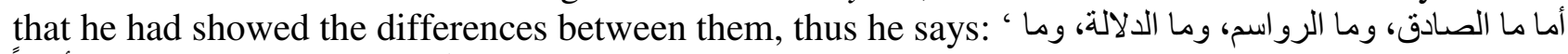
الفرق / concerning What are the true, mapping (rāsim), and sign, and what is the difference between them, we have clarified this here too' [TAR B, p.14; TAR L, p.13]. Even after his saying 'but the essence... etc.,' he tells us about this essence, thus he continues

$$
\text { / و أخبرنا أن من هذه أيضاً ما هو لعلة من العلل، غير ذى سلوجسموس، ومنها ما هو مسلجس، وحددنا ذلك وبيناه }
$$

And we said that there are also, for a cause among many causes, amongst those; what is not syllogistic and what is syllogistic, and we defined that and made it clear [TAR $\mathrm{B}, \mathrm{p}$. 14; TAR L, p. 14$]^{90}$.

$T A$ already spoke about non-syllogistic mappings ( $\mathrm{rawis}$ sim $)^{91}$. Moreover, he talkes about the cause of the non-syllogistic when he talkes about false signs:

ونحو آخر من قِبل العلامة، فإن هذا أيضاً بلا سلجسة... إن قال قائل إن ديانوسيوس> كان لصاً> لأنه شرير ؛ فهذا

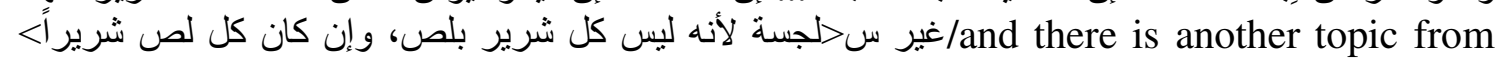
sign; this is not syllogism either...if one said that Dionysus <was a thieve $>$ because he was wicked, then this would not be $s<y$ llogistim because not every wicked man is a thieve, while every thieve is a wicked man $>^{92}$.

Moreover, the reader who is interested in On Rhetoric, like āl-Šăfi' $y$, will not be interested to go back to Analytics, because syllogism is specific to dialectics not rhetoric.

/ أعنى قولنا إن الريطورية مركبة من العلم الأنالوطيقى ومن الفوليطية النى فى الأخلاق' Concerning (b); TA says I mean our saying that rhetoric is composed of analytics and politics which is a part of ethics' [TAR B, p. 19; TAR L, p. 19].

Concerning the second point, i.e. the modification of Aristotle's Theory of argumentative rationality, this happened as follows: first, in TAR there are only two kinds of syllogisms (or saljasa) not three ${ }^{93}$, i.e. dialectical and rhetorical. Over all TAR there is no mention of analytical syllogisms, only the dialectical and rhetorical ones. Moreover, TA was always connecting the two later ones so that he gives the impression that there is no a third one ${ }^{94}$. This is being entrenched in the (ancient) reader's mind by the obscurity of TA's hints to Analytics already mentioned. Accordingly, there are only two types of argumentative rationality, i.e. dialectical and rhetorical (and the last one leads to truthfulness). Second, the concept of demonstration became very different from Aristotle's ${ }^{95}$. It is now aiming to persuasion ${ }^{96}$ without qualification, i.e. "و / التصديق إنما يكون بالتثبيت the thuthfulness has to be by demonstration.' Thus, in TAR there is no room for scientific deduction, there is only demonstration aiming at truthfulness. If the aim of the truthfulness, on the one hand, is refutation then the demonstration will be dialectical, and if the aim, on the other hand, is persuasive then the demonstration will be rhetorical. Rhetorical demonstration is of two kinds: (1) analogy or proof, and (2) syllogism or saljasa or thinking or the a fortiori. Third, the structure and meaning of syllogism has changed. In TAR the only passage about the nature of syllogism is very obscure and does not explain its very essence:

$$
\begin{aligned}
& \text { و النحو الذى يكون بأن يكون شىء موضوع يحدث من أجل شىء آخر سوى ذللك الموضوع بذللك الموضوع إلفو نفسه: } \\
& \text { and the way which being that something posited }
\end{aligned}
$$


happens because of another thing other than that posited thing but by that very posited thing, either universally or all the more is syllogism there $[T A R \mathrm{~B}, \mathrm{p} .11 ; T A R \mathrm{~L}, \mathrm{p} .10]^{97}$.

Thus, in TAR there is no mention of the major, middle and minor terms, therefore syllogism in TAR is just reasoning.

\section{2. āl-Šăfi' 'y's Theory of Argumentative Rationality}

I shall try now to reconstruct āl-Šăfi' $y$ 's theory of argumentative rationality showing how he followed $T A$.

\subsubsection{The General Framework}

First of all, āl-Šăfi ${ }^{`} y$, like $T A$, recognizes two kinds of argumentation. The first kind, like TAR, is dialectics or āl-jadal or āl-kalām which he rejects (there is no dialectics in TAR) because 'لو علم الناس if people know what inclination is in Kalām, then they will escape from it' [57, 203]. This underestimation stems from TAR's description of dialectics goal as just attacking [TAR B, p.8; TAR L, p.6] and that in dialectics we are pronouncing what we wanted and are inclined to بما شئنا وهوينا,' [TAR L, p.11]. In this last clause we have the verb hawā, while in ālŠăfi' 'y's we have its nominal plural $\bar{a} h w \bar{a}$ '. On the other hand, there is rhetorical argumentation or what āl-Šāfi'y calles bayān or perspicuous declaration as M. Khadduri translates it ${ }^{98}$. This bayān, in addition to its being God and his messenger's way of argumentation ${ }^{99}$, is also the way of muftis and judges for knowing what shall be acted if God and his messenger did not say anything about some case $^{100}$, and that is by reasoning or 'istidlāl [Risāla $\mathrm{K}:$ 70]. This reasoning is nothing but rhetorical qiyās [Risāla K: 121], which even God uses it in his argumentation ${ }^{101}$. Thus, āl-Šăfí ${ }^{6} \mathrm{y}$ borrowes TAR's general framework for argumentation.

To āl-Šāfi'y the first task for a mujtahid or a jurist is to judge; ' فاعلم أن للحاكم الاجتهاد، و المفتيين في فاعل that 'ijtihād is to judge, and muftis in the position of judging' [15 viii, p. 73]. This judgment is the equivalent of $T A$ 's 'truthfulness or äl-tașdyq'. Also, like TAR, there is no truthfulness without demonstration or tatbyt. Judges and muftis have to demonstrate their judgment. $\bar{a} l-\breve{S}_{a} \mathrm{fi}^{\prime} \mathrm{y}$ is using here the same term and its derivatives in TAR for demonstration, i.e. yut $\underline{t} b i t$, 'it $\underline{t} b \bar{a} t$, tatbyt and tatabbut. Thus, he says

أمر رسول الله فى الحكم خاصة ألا يحكم الحاكم وهو غضبان؛ لأن الغضبان مخوف على أمرين: أحدها قلة التثبت

I the messenger of God commanded with respect to the judgment especially that no judge should give judgment while angry, because the angry man may fall in two faults; one of them is lack of demonstration... [15 viii, p. 211 $]^{102}$.

āl-Šāfi'y is even using that term (tațbyt) for demonstrating the prophet's sayings or hadyt. Thus, he says: 'تفرق أهل الكلام فى تثبيث الخبر عن رسول الهاله ahl āl-kalām divided concerning how to demonstrate the messenger's sayings' [15 ix, p. 5] ${ }^{103}$. And he is also using the same term for demonstrating the sayings of the companions or Şahabā:

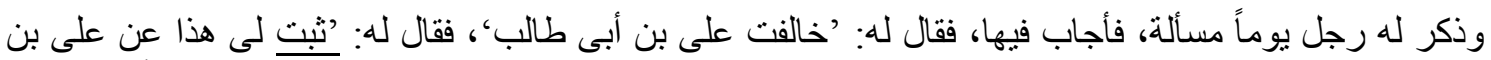
someone asked him someday a question, and he replied, then that man told him 'you disagreed with 'Aly Ibn Abw Ţālib', then he said to him 'demonstrate this to me from 'Aly Ibn Abw Ţālib'... [54 iii, p. 38].

\subsubsection{The Ways of Demonstration}

Following TA in saying that there is artificial and non-artificial truthfulness, āl-Šăfi' ${ }^{\prime} y$ defines (a) the latter as only the book and sunan / سنن , while he defines (b) the former as only analogy or the $a$ 
fortiori which (c) has reasoning by sign as a sub-category. This schema is matching with TAR as I shall show below.

\subsubsection{1. 'Uswl/Elements (Sunan Theory)}

TA divides customs or 'sunan' into two kinds, i.e. general and particular ${ }^{104}$. The particular one is specific for one man, while the general is absolute ${ }^{105}$. Both of them are binding for people ${ }^{106}$. The general sunna cannot be modified or changed, because 'ليست تكون بحيلة منا لكن بأمور متقدمة / we are not interfere in it because it is a priori' [TAR B, p. 9; TAR L, p.7] as TA says about non-artificial truthfulness. If the particular sunna contradicts with the general one, people have to obey to the general one ${ }^{107}$, therefore the general sunna is working as duty, while the particular one is working like derivative duty. In addition, the one who writes down sunan has to be a wise man, thus TA says:

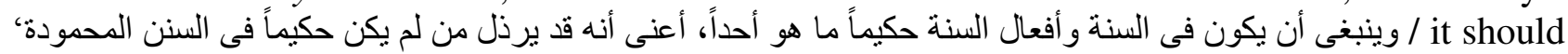
be in sunna and its actions some wise man who is unique, I mean that he who is not wise in the praised sunan, may be getting bad ${ }^{108}$.

Following TA âl-Šăfi'y calls both of TA's sunan 'usūl / elements' ${ }^{109}$, because they are nonartificial according TAR. These usūl / elements, as TA did, āl-Šăfi'y divides into two: the Qur'ān (the general sunna), and the messenger's sunna (the particular sunna) ${ }^{110}$. Thus, he says

لم أعلم مخالفاً فى أن من مضى من سلفنا والقرون بعدهم إلى يوم كنا قد حكم حاكمهم و أفتى مفتيهم فى أمور ليس I I did not know about anyone who objected that the people, who preceded us and their successors up to our day, had a judge who has judged and a mufti who has issued a fatwa in things had had not a book or a sunna [15 ix, p. 19].

This sentence proves that āl-Šăfi‘y read Aristotle and how he read him.

Before leaving this subsection I must refer to two remarks: the first one is related to the concept of sunna in āl-Šâfi' $y$ 's works which matches with TA's concept and attests my reconstruction. It is known that the concept of sunna, in its early developing phase 'as the traditional usage of the community' [82, p. 3; (cf. also, [23, p. 28]) up to āl-Šăfi‘y’s time when, with him, it became to signify mainly to 'the model behavior of the prophet' [82, p.2], was including the customs, practices, sayings...etc. of the messenger ${ }^{111}$. But there is also another meaning of ālŠafi'y's usage; that is sunna as a law or a legal rule. Thus, he says explaining one of the meanings of bayān: 'ما سن رسول الله مما ليس لله فيه نص محكم / what the messenger of God legitimated / sann in what God has no a concise text' [Risāla $K$ : 85; also 96; 292; 301 - 302]. Here, âl-Šâfí 'y' is using the verb 'sann' in the meaning of legitimating a law or a legal rule. This usage of 'sunna' is matching TA's meaning where the Syriac translator of Aristotle's On Rhetroic rendered vouós (law) as sunna (compare [64, p. 102]).

The second remark is related to āl-Šăfi'y's insistence on the wisdom or hikma of the prophet $^{112}$. As Lowry noticed, 'Shāfi'‘ 1 offers several arguments in support of the authority of Muhammad's Sunna, all of which depend on passages in the Qur'ān. ... The second concerns a number of passages in the Qur'ān in which the word hikma, 'wisdom,' is paired with the phrase 'God's Book' or an equivalent. In these passages, Shāfi'i tells us, Hikma means 'Sunna,' so that the passages may all be understood to refer to the complementary pair of the Qur'ann and the Sunna [64, p. 170]. But Lowry believed that this equivalence between Sunna and Hikma is a result to ālŠâfi'y's inventiveness [ibid., p. 186], and his using to a primitive Basran concept of equivalence between Sunna and Hikma [ibid., pp. 184-85]. But if my reconstruction is right, it will be more reasonable to believe that āl-Šăfi'y paired hikma with sunna because TAR insists on the necessity of the giver of sunna being a wise man.

The real inventiveness of āl-Šăfi' $y$ lies not in his usage of the primitive Basran concepts of hikma, but in (a) using this primitive equivalence for convincing scholars of his own time with his borrowed theory, and in (b) his considering that sunna is commanded in the Qur'ān itself [Risäla K: 244], thus he connected what $T A$ left unconnected, and by doing so he (c) escaped from the 
possibility that there could be a contradiction between the general sunna and the particular one; between the Qur'ān and the messenger's sunna, in case of the validity of sunna.

Accordingly; we do not need to J. Wegner's hypothesis of the borrowing of the concept of hikma from the Rabbinic literature [97, pp. 52 - 53], especially as Lowry has shown that the opposite is correct, namely that the $G e$ 'onic literature borrowed this concept from Islamic literature [64, pp. $185-186]$.

\subsubsection{The Artificial Demonstrating (qiyās)}

As I have shown before, āl-Šāfi'y considered qiyās to consist of two main mental activities, i.e. analogy and the a fortiori. By doing so he is following TA's argumentative rationality concerning the types of argumentation in rhetoric. TA considered that all artificial demonstrating is either by

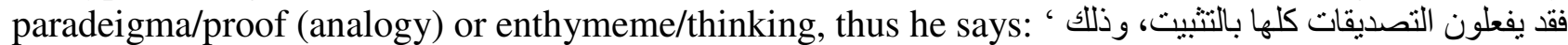
r they can fulfill all truthfulness by demonstration, and this is either by bringing proof/paradeigma or by thinking/enthymeme, there is nothing more than these two' [TAR B, p. 11; TAR L, pp. 9 - 10].

Similarly, âl-Šāfi'y paired 'ijtihād with qiyās, 'هما اسمان لمعنى واحد / they are two names but have the same meaning' [Risāla $\mathrm{K}: 1324]$. 'Ijtihād is a mental activity special to human beings, a / ومنه: ما فرض الله على خلقه الاجتهاد فى طلبه، His creatures to seek through 'ijtihād (personal reasoning)' [Risāla K: 59; Risāla M: 68]. This و أما اللاتى بالصناعة فما أمكن ' consideration of 'ijtihād as mental activity goes back to TA's saying that إعداده وتثييته على ما ينبغى بالحيلة وأنفسنا what can be prepared and demonstrated by trick and by ourselves as they should be' (TARB, p. 9). Of course the term ' 'ijtihād' had a history before āl-Šăfi' ${ }^{113}{ }^{13}$, but āl-Šăfi' $y$ 's inventiveness lies in his integration of that history with TAR's theory of argumentative rationality especially as the translator of TAR rendered enthymeme as thinking/فكر/تفكير, and we know how the meaning of fikr, 'ijtihād and $r \bar{a}$ 'y are so interrelated to.

My reconstruction can answer some puzzling questions about āl-Šăfí'y’s rationality. The first question is relating to āl-Šāfi'y's argumentative rationality: Why did āl-Šăfi ‘y consider the $a$ fortiori to be stronger than analogy? ${ }^{114}$ This question can be answered easily by citing some texts from TAR which confirm superiority of the a fortiori or thinking over analogy or proof. Thus, TA says: 'التنثيت الريطورى هو التفكير، لان هذا في الجملة هو الأصل المتقدم للتصديقات / the rhetorical demonstration is thinking, because it is in the main the prior principle of truthfulness' [TAR B, pp. 6-7; TAR L, p. 4]. Also: 'التفكيرات التى هى عمود التصديق / thinkings/enthymemes (which) are the pillar of truthfulness' [TAR B, p.4; TAR L, p.1]. Also,

$$
\begin{aligned}
& \text { فقد ينبغى أن نستعمل البرهانات فى التتبيت إذا لم يكن الكلام موضع تفكير[فى التتبت إذا لم يكن فى الكلام موضع } \\
& \text { [ we should use proofs/analogy in demonstration if the speech } \\
& \text { was not thinking/enthymeme[in demonstration if there were not thinking in speech], } \\
& \text { because truthfulness is by this (thinking) [TAR B, p.141; TAR L, p.136]. }
\end{aligned}
$$

The second question is relating to the relationship between āl-Šăfi' $y$ 's argumentative rationality and TA's: why did āl-Šăfi' $y$ choose only the a fortiori argument from all the kinds of enthymemes topics which TA offered? This is for two reasons. Firstly, the Jewish or Hebrew rules of hermeneutics did not recognize any enthymemic rules except the a fortiori, and āl-Šăfi ‘y was a follower of the $R S$ without following their contents as we have shown before. Secondly, the mistranslation of Aristotle's On Rhetoric or TAR. This mistranslation identified the a fortiori and the most part premises, and by doing so made the a fortiori the most important topic of enthymeme. This happened in two passages ${ }^{115}$ Aristotle was talking in both of them about the most part premises but the translation rendered them as if Aristotle were talking about the a fortiori (and sign) as the most important enthymemic topic. I shall discuss here the first passage which was quoted before. In this passage [24, 1356b 15-16], Aristotle talks about how (dialectical) syllogism is the counterpart to 
enthymeme, but the translation identifies enthymeme and the a fortiori as follows:

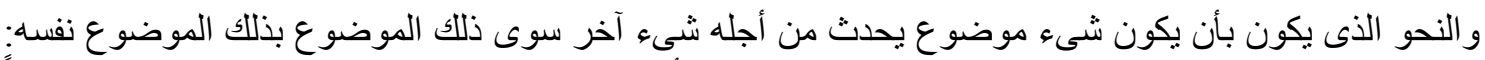
إما / and the way which being that something posited happens because of another thing other than that posited thing but by that very posited thing, either universally or all the more is syllogism there and called thinking here [TAR B, p.11; TAR L, p.10].

If you do not already know what Aristotle means by 'the most part,' and of course you do not know in case you read only TAR, you will identify it as 'all the more', and that is what âl-Šăfi' $y$ did. Thus, the topic of the a fortiori (and its supplements as we shall see in the next subsection when we shall analyze āl-Šăfi' $y$ 's concept of sign) became thinking/enthymeme itself, therefore there were no need for the other topics of enthymeme.

\title{
5.2.2.3. The Premises of Demonstration and Inference by Sign
}

In fact, āl-Šăfi' 'y did not borrow only the 'more and the less' topic from TAR, but he also borrowed 'sign' topic ${ }^{116}$. This becomes because TA's talking about the sign relates it to 'the more and less' topic. In the previous subsection I have analyzed two mistranslated passages which made Aristotle talks about 'the more' topic instead 'the premises of the most part'. In the Greek original text Aristotle says: 'it is evident that [the premises] from which enthymemes are spoken are sometimes necessarily true but mostly true [only] for the most part' [24, 1357a 31-33]. While TA says: ' فهو معلوم it is known now that from these which called thinkings there is what is necessary, and many of them [i.e. thinkings] exist as all the more' [TAR B, pp.13-14; TAR L, p.12]. After that Aristotle talks immediately about the premises of enthymeme and how they should be either probabilities or signs, but the translator(s) of $O n$ Rhetoric changed the meaning and made the premises of enthymeme or $\bar{a}$-tafkyrāt being the true propositions or $\bar{a} l$-șadiqāt and signs or $\bar{a} l$-dalä'il. This is very interesting because making the premises of enthymeme/āl-tafkīrāt as the true propositions gave āl-Šăfi' $y$ the justification for considering them as God's duties. On the other hand, TA's consideration signs/الدلائل as another category of enthymemes or āl-tafkyrāt was adopted by āl-Šāfi'y. He even borrowed the term dalyl (sign) for describing this kind of inference: 'ومعنى هذا الباب معنى القياس، لأنه يطلب فيه الدليل على صواب القبلة / the meaning of this subject is the same as the meaning of qiyās, because in it a sign is sought for the right direction in prayer' [Risāla K:121]. He also defines qiyās as sign (daläla): ' القياس ما طلب بالدلائل qiyās is what was sought by signs' [Risāla K: 122]. āl-Šāfi'y tries to justify'ijtihād and qiyās through finding a justification of inferring by sign from within the Qur'ān. Thus, after quoting $Q: 16-16$ he says:

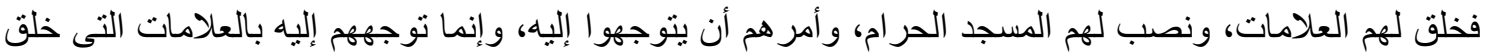

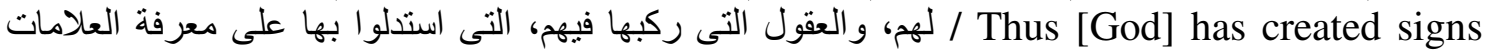
('alāmāt) [for men to be guided by] and erected the sacred Mosque and ordered them to turn their faces towards it [in prayer]. Their turning in that direction [is determined] by the signs He created for them and by reason which He has implanted in them and by which they are guided to recognize the signs [Risāla K:114].
\end{abstract}

\section{Conclusion}

In this paper, I have tried to outline a history of the development of informal logic at the Arabic and Islamic culture as it appeared in the first definite formulations for its rules in āl-Šăfi' $y$ 's Risāla. I have followed this development in the fields of law, exegesis and rhetoric. Contrary to J. Schacht and others, I have argued that, there was no influence on the informal logic of the Arabs by the rhetorical Hellenistic schools of Mesopotamia, or by the Jews of Iraq ${ }^{117}$. The main influence was 
from the Rabbis of Yemen who translated orally the Fathers to Rabbi Nathan which contained Jewish or Hebrew informal logic rules. This could not have happened without a translation movement which I have called 'Umar's translation movement. This is contrary to D. Gutas' [42] hypothesis that the translations into Arabic before Abbasid times' were mainly administrative or for communicative purposes. There was indeed a disciplined translation movement before the Abbasid's. However, the Jewish or Hebrew informal logic spread amongst the scholars of exegesis and law especially in the school of Ibn 'Abbās (the secretary of the first disciplined movement translation) from which āl-Šăfi' ‘y learnt these rules. āl-Šăfi ‘y also coined the term qiyās, which was current in Medina's linguistic school, to include the a fortiori and analogy. Having been confronted with Iraqi scholars, he articulated the Hebrew logic by Aristotle's On Rhetoric from which he borrowed his argumentative rationality. In doing so he returned to the founder of informal logic unlike the Rabbis who learnt informal logic from the Hellenistic rhetorical schools ${ }^{118}$. Accordingly, âl-Šăfi'y developed the Semitic informal logic even though he partly misunderstood Aristotle because of the mistranslation into Arabic of the latter's On Rhetoric. Thus, my paper brings us to further researches. Firstly, analyzing āl-Šāfi' 'y's informal logic formally and comparing it with its Hebraic counterpart syntactically and semantically. Secondly, tracing 'Umar's translation movement, especially that 'Uțmān Ibn 'Affān (d. 35/656) the third caliph permitted Tamym āl-Dāry to continue story telling ${ }^{119}$ (translation), and $\mathrm{Ka}^{\circ} \mathrm{b}$ established a new generation of translators, i.e. his sons ${ }^{120}$. And if we can trace this movement, then we may solve partly the methodological problem in Arabic and Islamic scholarship concerning the authenticity of Hadyt and the sayings of the companions and the successors. Thirdly, because of the influence of Aristotle on 'uswl al-fiqh as I have proved, there is a need to reexamination of the relationship between fiqh or rathar 'uswl älfiqh and rhetoric and philosophy in the Arabic and Islamic systems of knowledge, especially as both Arabic and Islamic philosophy depended on the misunderstanding of Aristotle because of its Arabic translation $^{121}$.

\section{Acknowledgement}

I would like to thank professor Dr. Regula Forster for her helpful notes and critical comments on this paper, and I do not need to say that any mistakes are only mine. Also, I would like to thank Erasmus Mundus foundation for its financial supporting writing this paper.

\section{References}

1. Abdel-Rahman, H. L'argument a maiori et l'argument par analogie dans la logique juridi-que musulmane, Rivista Internazionale di Filosofia del Diritto, 98, 1971, pp. 127-148.

2. Abdul-Raof, H. Schools of Qur'anic Exegesis, London and New York: Routledge, 2010.

3. āl-Bayhaqy, āl-Jami' li Shu 'ab āl-’ymān. Maktabat āl-Rushd: āl-Riyaḍ, 2003.

4. āl-Bayhaqy, Manāqib āl-Šăfi 'y. Dār āl-Turāt: Cairo, 1970.

5. āl-Buk̄āry, āl-Jāmi ‘ āl-Şaḥyḥ. Dār Țawq āl-Najāḥ: āl-Madyna āl-Munawwara.

6. āl-Haytamy, Kašf āl-Āstār 'an Zawā' '̄̀ āl-Bazzār. Mw'asasat āl-Risāla: Beirut, 1979.

7. āl-Jahiz, āl-Bayān wa āl-Tabyyn. Maktabat āl-Kānjy: Cairo, seventh edition, 1998.

8. āl-Katỵb āl-Baḡdādy, Kitāb āl-Faqyh wa āl-Mutafaqqih. Dār Ibn āl-Jawzy: āl-Riyaḍ, 1996.

9. āl-Ǩatyb āl-Baḡdādy, Tāryk Baḡdād. Dār āl-Ḡarb āl-'Islāmy: Beirut, 2001.

10. āl-Mizzy, Tahdיyb āl-Kamāl fy Assmā' āl-Rijāl.Mū'asasat āl-Risāla: Beirut, second edition, 1983.

11. Alnashar, A. S. Manāhij āl-Baḥt 'ind Mufakkiry āl-’Islām. Dār āl-Nahḍa āl-'Arabya: Cairo, 1984.

12. āl-Rāzy, Kitāb āl-Jurh wa āl-Ta 'dyl. Dār āl-Kutub āl-‘Ilmya: Beirut, 1953.

13. āl-Şan‘āny, āl-Tanwyr Šarḥ āl-Jami`‘ āl-Şaḡyr. Dār āl-Salām: āl-Riyaụ, 2011. 
14. āl-Šāfi‘y, Risāla. Maktabat Muștafā āl-Halaby: Cairo, second edition, 1983.

15. āl-Šāfi‘y, Umm. Dār āl-Wafā’ lil Ţibā‘a wa āl-Našr: āl-Manswra, 2001.

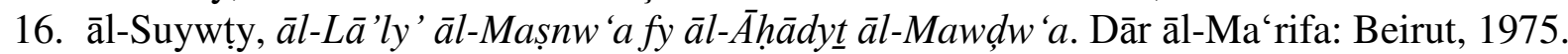

17. āl-Tirmid̄y, āl-Jāmi ‘ àl-Kabyr. Dār āl-Ḡarb āl-’Islāmī: Beirut, 1996.

18. āl-Ţabarāny, āl-Mu jam āl-Kabyr. Maktabat Ibn Taymya: Cairo, 2015.

19. āl-Ţabary, Jāmi ' āl-Bayān 'an Tā'wyl àl-Qur'ān. Maktabat Ibn Taymya: Cairo, 1953.

20. āl-Ţabary, Taryk āl-Rusul wa āl-Mlwk. Dār āl-Ma'ārif, second edition: Cairo, 1967.

21. āl-Dahaby, Myzān āl-'I'tidāl fy Naqd āl-Rijāl. Dār āl-Ma'rifa: Beirut, 2009.

22. āl-D̃ahaby, Siyar Ā'lām āl-Nubalā'. Mw'asasat āl-Risāla: Beirut, eleventh edition, 1996.

23. Ansari, Z. I. Islamic juristic terminology before Šāfi ${ }_{1} \overline{1}$ a a semantic analysis with special reference to Kūfa, Arabica, vol. 19, Fasc. 3, 1971, pp. 255-300.

24. Aristotle, On Rhetoric: A Theory of Civic Discourse, trans. by G. A. Kennedy, Oxford: Oxford University Press, 2007.

25. Aristotle, Topics, In J. Barnes (ed.), The Complete Works of Aristotle, trans. by W. A. PickardCambridge, Princeton: Princeton University Press, 1991.

26. Avoth de Rabbi Nathan, Edited from Manuscripts with an Introduction, Notes and Appendices by S. Schechter (Hebrew), Vienna, 1887. (Reprint, Hildesheim; New York: G. Olms Verlag, 1979.)

27. Azzan, Y. Scripture as logos: Rabbi Ishmael and the origins of Midrash, Philadelphia: Pennsylvania University Press, 2004.

28. Badawi, A. Arisțutālīs: āl-Khițaba. Dar āl-Qalam: Beirut, 1979.

29. Berg, H. The Development of Exegesis in early Islam, London and New York: RoutledgeCurzon, 2000.

30. Biesen, K. D. Simple and Bold: Ephrem's Art of Symbolic Thought, New Jersey: Gorgias Press, 2006.

31. Bravmann, M. M. The Spiritual Background of Early Islam, Leiden: Brill, 1972.

32. Brock, S. P. A Brief Outline of Syriac Literature, India: Deepka Offset Printers, 1997.

33. Cadler, N. Ikhtilâf and Ijmâ' in Shâfi'î 's Risâla, Studia Islamica, 58, 1983, pp. 55-81.

34. Chaumont, E. ĀL-SHĀFI'I, In C. E. Bosworth, E. van Donzel, W. P.Heinrichs and G. Lecomte (eds.), The Encyclopaedia of Islam, 85, Leiden: Brill, 1997, pp.181-85.

35. Coulson, N. J. A History of Islamic Law, Edinburgh: The University Press, 1964.

36. Danish Pazuh, M.N.T. Mantiq Ibn āl-Muqaffa'. Anjuman-i Shahanshahi Falsafah-i Tihran, Tehran 1978.

37. Faḳr āl-Dyn āl-Rāzy, Manāqib āl-'Imām āl-Šâfi ‘y. Maktabat āl-Kwliyāt āl-Āzhariya: Cairo, 1986.

38. Goldfeld, Y. The Development of Theory on Qur'ānic Exegesis in Islamic Scholarship, Studia Islamica, 67, 1988, pp. 5-37.

39. Goldin, J. The Fathers according to Rabbi Nathan, New Heaven: Yale University Press, 1955.

40. Goldziher, I. Introduction to Islamic Theology and Law, trans. by A. and R. Hamori, Princeton: Princeton University Press, 1910/1981.

41. Goldziher, I. The Zāhirīs, trans. and edited by W. Behn, Leiden: Brill, 2008.

42. Gutas, D. Greek Thought, Arabic Culture, London: Routledge, 1998.

43. Hallaq, B. W. The Development of Logical Structure in Sunni Legal Theory, Der Islam, 64, 1987, pp. 42-67.

44. Hallaq, B. W. Non-Analogical Arguments in Sunni juridical Qiyās, Arabica, vol. 36, Fasc. 3, 1989, pp. 286-306.

45. Hallaq, B. W. A History of Islamic Legal Theory, Cambridge: Cambridge University Press, 1997.

46. Hallaq, B. W. The Authenticity of Prophetic Hadîth: A Pseudo-Problem, Studia Islamica, No. 89, 1999, pp. 75-90.

47. Hallaq, B. W. The Origins and Evolution of Islamic Law, Cambridge: Cambridge University Press, 2005.

48. Hallaq, B. W. An Introduction to Islamic Law, Cambridge: Cambridge University Press, 2009. 
49. Hunt, E. J. Christianity in The Second Century: The Case of Tatian, London and New York: Routledge, 2003.

50. Ibn Abw Dawwd, Kitāb āl-Mașāhif. Dār āl-Bašā'̄̄r āl-'islāmiya: Beirut, second edition, 2002.

51. Ibn Abw Kaytama, āl-Tāryk āl-Kabyr. āl-Fārwq āl-Ḥadytāa lil Țibā'ā wa āl-Našr: Cairo, 2004.

52. Ibn Abw Šaybā, āl-Muṣannaf. Maktabat āl-Rushd: āl-Riyaḍ, 2004.

53. Ibn āl-Mūqaffa', Risālat āl-Şahāaba. In: Ātāar Ibn āl-Mūqaffa'. Dār āl-Kutub āl-'Ilmiya, Beirut, 1989, pp. 309-24.

54. Ibn āl-Nadym, āl-Fihrist. Mu'asasat āl-Furqān lil Turāt āl-’'Islāmy: London, 2009.

55. Ibn 'Asākir, Tāryk Madynat Dimašq. Dār āl-Fikr: Beirut, 1995.

56. Ibn Hanbal, A. Musnad. Bayt āl-Āfkār: āl-Riyaḍ, 1998.

57. Ibn Katyr, Manāqib āl-'Imām āl-Šāfi 'y. Maktabat āl-’Imām āl-Šāfi‘y: āl-Riyaḍ, 1992.

58. Ibn Kaldwn, The Muqaddimah, 3 vol., trans. by F. Rosental, Princeton: Princeton University Press, 1958.

59. Ibn Manzwwr, Lisān āl- 'arab. Dār Nwbilys: Beirut, 2006.

60. Ibn Muḱallad āl- Šaybāny, Kitāb āl-Sunna. āl-Maktab āl-’Islāmy: Beirut, 1980.

61. Ibn Sa‘d, Kitāb āl-Ţabaqāt āl-Kabyr. Maktabat āl- Kֵānjy: Cairo, 2001.

62. Khadduri, M. Islamic Jurisprudence: Shāfi ‘' ${ }^{\prime} s$ Risāla, Translated with an Introduction, Notes, and Appendices, Baltimore: The Johns Hopkins Press, 1961.

63. Lowry, J. E. Does SHĀFI'Ī have a theory of 'four sources' of law? In R. Peters and B. Weiss (eds.), Studies in Islamic law and society, Leiden: Brill, 2002.

64. Lowry, J. E. Early Islamic Legal Theory: The Risāla of Muhammad ibn Idrīs āl-Šāfi 'y, Leiden: Brill, 2007.

65. Lyons, M. C. Aristotle's Ars Rhetotica: The Arabic Version, A new edition with Commentary and Glossary, vol. 1, Text. Cambridge: E. \& E. Plumridge Ltd., Linton, 1982.

66. Lyons, M. C. Aristotle's Ars Rhetotica: The Arabic Version, A new edition with Commentary and Glossary, Vol. 2, Glossary. Cambridge: E.\& E. Plumridge Ltd., Linton, 1982.

67. Margoliouth, D. S. Omar's Instructions to the Kadi, Journal of the Royal Asiatic Society of Great Britain and Irland, 1910, pp. 305-336.

68. Margoliouth, D. S. The Early Development of Mohammedanism, London: Williams and Norgate, 1914.

69. Marrou, H. I. Education in Antiquity, trans. by G. Lamb, New York: The American Library, 1956.

70. Motzki, H. The Role of Non-Arabs Converts in the Development of Early Islamic Law, Islamic Law and Society, vol. 6, no. 3, 1999, pp. 293-317.

71. Motzki, H. The Origins of Islamic Jurisprudence: Meccan Fiqh before the Classical Schools, Leiden: Brill, 2002.

72. Moubarez, H. The Development of the Semitic Logical Traditions: 1. The Hebraic Logical Tradition up till the End of third Century (In Arabic), The Proceedings of the international conference of the oriental languages department, Cairo: Cairo University Press, 2013, pp. 15-84.

73. Muqāțil Ibn Sulaymān, Tafsyr Muqāțil Ibn Sulaymān. Mw’asasat āl-Tāryk āl-'Araby: Beirut, 2002.

74. Muslim, Sahih Muslim. Dār āl-Kutub āl-'Ilmya: Beirut, 1991.

75. Neusner, J. A History of The Jews in Babylonia. vol. I. second edition. Brill: Leiden, 1969.

76. Neusner, J. The Rabbinic Traditions about the Pharisees before 70: Part I The Masters, Leiden: Brill, 1971.

77. Neusner, J. The Fathers According to Rabbi Nathan: An Analytical Translation and Explanation, Atlanta: Scholars Press, 1986.

78. Rippin, A. Literary Analysis of Qur'ān, tafsīr, and sīra: the Methodologies of John Wansbrough, In R. C. Martin (ed.), Approaches to Islam in Religious Studies, Tucson: The University of Arizona Press, 1985, pp. 151-163.

79. Rubin, U. Exegesis and Hadyt: the Case of the Seven mathānī, In G. R. Hawting and AbdulKader A. Shareef (eds.), Approaches to the Qur'ān, London: Routledge, 1993, pp. 141-156. 
80. Saldarini, A. I. The Fathers According to Rabbi Nathan version B: A Translation and Commentary, Leiden: Brill, 1975.

81. Schacht, J. A. Revaluation of Islamic Traditions, Journal of the Royal Asiatic Society of Great Britain and Ireland, 2, 1949, pp. 143-154.

82. Schacht, J. The Origins of Muhammadan Jurisprudence, Oxford: The Clarendon Press, 1950a.

83. Schacht, J. Foreign Elements in Ancient Islamic Law, Journal of Comparative Legislation and International Law, Third Series, vol. 32, no. 3/4, 1950b, pp. 9-17.

84. Schacht, J. An Introduction to Islamic Law, Oxford: Clarendon Press, 1982.

85. Schumann, A. Talmudic Logic. UK: Lightning Source, Milton Keynes, 2012.

86. Sifra, trans. and commentary by M. Ginsberg, Atlanta: Scholars Press, 1999.

87. Sion, A. Judaic Logic: A Formal Analysis of Biblical, Talmudic and Rabbinic Logic, Geneva: Slatkine, 1995.

88. Street, T. Arabic Logic, In D .M. Gabbay and J. Woods (eds.), Handbook of History of Logic, vol.1: Greek, Indian and Arabic Logic, North-Holland: Elsevier, 2004, pp. 523-596.

89. Talmon, R. On An Eighth-Century Grammatical School in Medina: The Collection and Evaluation of the Available Material, Bulletin of the School of Oriental and African Studies, University of London, vol. 48, 2, 1985, pp. 224-236.

90. Tatian, Address to the Greeks, In The Writings of Tatian and Theophilus; and The Clementine Recognitions, transl. by B. P. Pratten, M. Dods and Thomas Smith D. D., Edinburgh: T\&T Clark, 1967, pp. 1-45.

91. The Jursalem Talmud: Second Order: Mo'ed; Tractates Pesahem and Yoma, trans. And commentary by H. W. Guggenheimer, Berlin: Guyter, 2013.

92. The Tosefta, trans. by J. Neusner, vol. 2, Massachusetts: Henrickson Publishers, 2002.

93. Triyanta, A. Greek Philosophy And Islamic Law (The Influence of Aristotle's Logic on Analogical Qiyas in Shafi'i's Risala), Logika, 5, 2001, pp. 11-33.

94. Vagelophil, U. The Syriac and Arabic Translation and Commentary Tradition, Leiden, Brill, 2008.

95. Versteegh, K. Landmarks in Linguistic Thought III: The Arabic Linguistic Tradition, London and New York: Routledge, 1997.

96. Wansbrough, J. Quranic Studies: Sources and Methods of Scriptural Interpretation, Oxford: Oxford University Press, 1977.

97. Wegner, J. R. Islamic and Talmudic Jurisprudence: The Four Roots of Islamic Law and Their Talmudic Counterparts, The American Journal of Legal History, vol. 26, no. 1, 1982, pp. 25-71.

98. Wymann-Landgraf, U. F. A. Malik and Medina: Islamic Legal Reasoning in the Formative Period, Leiden: Brill, 2013.

99. Ziembinski, Z. Practical Logic, Dordrecht: Reidel, 1976.

\section{Notes}

1. The analysis of the Arabic informal logic, in a formal way, unlike the Hebrew one has not received attention. However, we have tentative attempts in [1] [43] [44].

2. Schacht [82] wrote a whole chapter about the earlier Islamic logical techniques in law such as analogy, but to integrate it in his history of Islamic legislation. So did Coulson [35], although his address for analogy is more limited [ibid., pp. 40; 72-3; 59-60]. Hallaq in his history [45] is not interested in the development of such techniques but rather in introducing an outline of the logical structure for the earlier Islamic legislation and beyond. But in his Origins and Evolution of Islamic Law [47 ch. 5.3] [cf. Also his 48, pp. 19-27] he avoids this fault by displaying an excellent brief history of Islamic legal logical techniques. Although Wymann-Landgraf [98] has 'Islamic Legal Reasoning in the Formative Period' as a subtitle, only half of its first part addresses the informal logic [ibid., pp. 85-182], while its main concern is not a history of Arabic informal logic, but is 'fundamentally concerned with Medinese praxis ('amal), a distinctive non-textual source of law which lay at the foundation of Medinese and subsequent Maliki legal reasoning' [ibid., p. 3].

3. Thus, Margoliouth [67, p. 320] and Schacht [82, pp. 99-100] insisted on the Jewish influence upon the Islamic logical toolkit. Hallaq accepts only the existence of some Semitic (including Jewish) laws in Islamic law [47, pp. 4; 27 - 
28; 194] while he rejects in his presentation of the Islamic legal and logical thinking any Hebrew influence [ibid., pp. 113-18] [also, 48, pp. 19-27]. Wymann-Landgraf [98] is entirely silent about this.

4. Some call it 'Judaic Logic' [87], others 'Talmudic Logic' [85]. But we prefer to call it Hebrew in order to be compatible with the other branches of Semitic logics, i.e. 'Arabic Logic' and 'Syriac Logic'. To wit: Logic for every Semitic language.

5. For the division of Tann'ayitic traditions into two schools [75, pp. 156-77]. For the division of the Tann'ayitic methods of interpretation into two traditions ('Akiva and Yišm'a'el), (see Ginsberg's [86] introduction to his translation of Sifra, pp. lvi-lx). And for the division of Hebrew informal logic into two traditions [72, pp. 69-73].

6. See section 3 below.

7. Tatian was an Assyrian orator and theologian who had a great influence on Syriac Christianity through his gospel harmony Diattessaron [49, pp. 144-75]. He was educated in a Hellenistic system [ibid., p. 1] which included Greek rhetoric which, in turn, included informal logic [69, pp. 148, 238-42]. Thus, in his oration to the Greeks, he uses these informal logical techniques such as analogy for proving resurrection [90, pp. 10-11].

8. Ephrem uses many informal logic techniques such as analogy [30, p. 67].

9. The Jerusalem Talmud. Pes. 6:1, fol. 33a says: 'From heqqeš: Since the continual offering is a community sacrifice and the pesah is a community sacrifice, just as the continual offering, a community sacrifice, overrides [the] Sabbath, so the pesah, a community sacrifice, overrides the Sabbath' (Neusner's [76] trans. P. 247). This inference has the following structure: A is C, B is C, C has D; then A has D and B has D. The common element is C (which has D).

10. In this paper, I shall use two editions of āl-Šāfi 'y's Risāla. The first one is M.S.Kilani's edition [14] and I shall refer to it as 'Risāla K'. The other one is M. Khadduri's translation of the Risāla [62] and I shall refer to it as 'Risāla M'.

11. Triyanta did not decide upon which text āl-Šăfi' ${ }^{\prime} y$ depended in his identification of qiyās as syllogism. He just made an abstract comparison between āl-Šăfi'y's qiyās and Aristotle's syllogism. Thus, he says that his 'thesis only tries to compare Aristotle's syllogism to analogical qiyās' [93, p. 15].

12. Ibn āl-Muqaffa"s treatment of qiyās comes during his discussion of the difference between the judgments. Thus, he saw that that difference was due to the difference between the ancestors' opinions or was a result to 'an opinion made by its people by qiyās which differed and spread because of a mistake in the principle of commensurability and initiated an issue on its wrong example / رأى أجر اه أهله على القياس فاختلف و انتثر بغلط فى أصل المقايسة وابتدأ أمر على غير مثاله [53, p. 317]. It is clear here that ibn āl-Muqaffa': (a) understands qiyās as analogy not syllogism, (b) this understanding is different from Ishmael's school in Babylonia.

13. There are many copies of this letter beginning from the one which is in āl-Jāhiz' āl-Bayān wa äl-Tabyyn [7] up to the one which is in Ibn Kaldwn's Muqaddimah [67, p. 307].

14. It was reported that he had a copy of the Bible or some religious book [60, H50] [52, H26828] [56, H15223].

15. '... the prophet said that 'Umar had come to him and said 'we like sayings we hear from Jews, do you think we

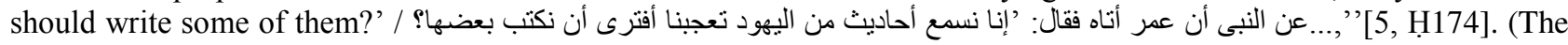
three points before the quoted text refer to an omitted ascription chain).

16. 'Jabir said that 'Umar had copied a book from the Torah into Arabic' [6 i , H124. cf. also, H125-126].

17. 'Zūhary said āl-Sa'yb b. yazyd had said that the first one to have told stories had been Tamym āl-Dāry; the later asked 'Umar for that and the later permitted him' [22 ii, p. 443] [cf. also, 55 xi, p.80].

18. 'When 'Umar had consulted people he [Ka'b] preceded them' [55 l, p. 158].

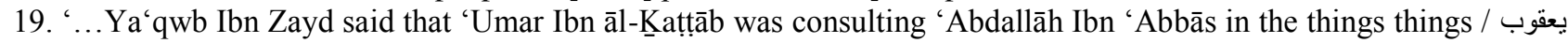

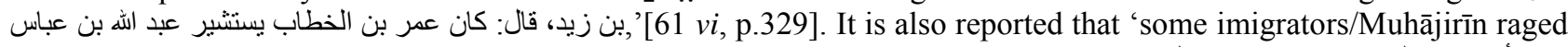
on 'Umar's his bringing Ibn 'Abbās closer to him than them / كان أناس من المهاجرين قد وجدوا على عمر فى إدنائه ابن عباس دونهم' [ibid., p.328] [ cf. also, 29, p. 130]. For his influence by the Jews see [2, p. 149].

20. Thus, we should stand with those scholars (for example: H. Birkeland, H. Gätje, C.H.M. Versteegh, F. Leemhuis and C. Gilliot) who insisted on existing of interesting in exegesis of the Qur'ān amongst the companions against those scholars (I.Godziher, A. Rippin and J. Wansbrough) who insisted on existing opposition of that interest. See [2, pp. 8-9] for more details and literature.

21. For the debate about dating of the collection of the Qur'ān, see Motzki, H. 'The collection of the Qur'ān: A reconsideration of Western views in light of recent methodological developments,' in: Der Islam, 78, pp. 1-34, 2001.

22. In all the reports we have previously quoted, Muhammad was denying 'Umar's behavior, for example he said having seen 'Umar's copying a paper from the Torah 'do not ask the people of the book about anything / لا تسألو ا أهل

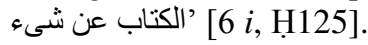

23. It was reported that there were oral translation of the Torah during Muhammad's life: '...Abw Hurayra said that the people of the book was reading the Torah in Hebrew and explaining it in Arabic for the Muslims' [5 ix, H7542].

24. It can be said that the movement of translation had its roots in Muhammad's era whereas it was reported that he had asked Zayd Ibn Tāabit to have learnt Hebrew or Syriac [61 ii, p.30]. Thus, we can say that there were two persuasive traditions; one confirmed translation and borrowing from the ancient books and the other denied this. 'Umar I have chosen the first.

25. '...Ka'b was telling stories / كعب كان يقص' [55 l, p. 170].

26. 'Umar I was not trusting in foreign scribes, therefore he appointed Ibn 'Abbās as a secretary of what was being transmitted from the ancient books. There are many reports support this hypothesis; once Tamym said, while telling stories and 'Umar I and Ibn 'Abbās was attending, 'Fear the scholar's err... then 'Umar said to Ibn 'Abbās when 
اتقوا زلة العالم...فقال [عمر] لابن عباس: إذا فرغ فاسأله: ما زلة / Tamym finished ask him about the meaning of the scholar’s err العالة العالم؟ [ibid., p.81]. Also, Ibn 'Abbās was beside 'Umar I during his last moments and was the link between 'Umar I and the people [61 iii, p. 323].

27. [61 ix, p. 449] [55 l, p. 159].

28. 'The Arabs had no books or scholarship. The desert attitude and illiteracy prevailed among them. When they wanted to know certain things that human beings are usually curious to know, such as the reasons for the existing things, the beginning of creation, and the secrets of existence, they consulted the earlier People of the Book about it and got their information from them. The People of the Book were the Jews who had the Torah, and the Christians who followed the religion of (the Jews). Now, the people of the Torah who lived among the Arabs at that time were themselves Bedouins. They knew only as much about these matters as is known to ordinary People of the Book,' [58 $i$, p. 566]. The western scholars followed Ibn Kaldūn steps, after adding the Talmud to the stock of those Jewish Bedouins.

29. The title 'A $h b \bar{a} r$ ' is the plural of the noun ' $h a b r$ ' which means Rabbi. Concerning Ka'b knowing of the rabbinic books we have the following report 'Ka'b said that my father had written for me one book of the Bible and having قال كعب: إن أبى كتب لى كتاباً من التور اة ودفعة / given it to me had told me to work by it, then he had sealed all his other books [61 ix, p.449] [cf. also, [55 l, p. 159].

30. Ka'b said 'My father was the most knower man of what God gave to Moses, and he did not keep anything he knew away from me / كان أبى من أعلم الناس بما أنزل اله على موسى، وكان لا يدخر عنى شيئاً مما بعلم '55 l, p.161]. Ka‘b also complained that the Rabbis blamed him for his conversion to Islam [ibid., p.164].

31. âl-Dahaby [22 iii, p. 489] also says that he [Ka'b] 'was telling them [Muslims] about the Israelite books.'

32. For this classification of the authenticity of the sayings of the prophet, see [46, p.76] [29, ch. 2]. For the authenticity of the exegetical traditions including Ibn 'Abbās' ones, see: [29, ch. 3].

33. Cf. also, [29, p. 40].

34. Cf. also, [ibid., p. 79].

35. This is the position of Fuat Sezgin in his Geschichte des arabischen Schrifttums, Band I: Qur'änwissenschaften, Hadith, Geschichte, Fiqh, Dogmatik, Mystik bis ca. 430 H., Leiden: Brill, 1967. And, N. Abbot in her Studies in Arabic Literary Papyri, II: Qur'ānic Commentary and Tradition, Chicago: The University of Chicago Press, 1967.

36. For Rippin's criticism of the alleged authenticity of the attributed books to Ibn 'Abbās, see his: 'Ibn 'Abbās's ālLughāt fi āl-Qur'ān,' in: Bulletin of the School of Oriental and African Studies, vol. 44, pp. 15-25, 1981; 'Ibn 'Abbās's Gharīb āl-Qur'ān,' in: Bulletin of the School of Oriental and African Studies, vol. 46, pp.332 333, 1983; 'Tafsīr lbn 'Abbās and criteria for dating early tafsīr texts,' in: Jerusalem

Studies in Arabic and Islam, vol. 19, pp. 38-83, 1994; and 'Studying early tafsīr texts,' in: Der Islam, vol. 72, pp. 310323, 1995.

37. See Schoeler, G., The Oral and the Written in Early Islam, trans. By U. Vagelpohl, London \& New York: Routledge, 2006, passim.

38. What I mean here is that these sayings were not just sayings or ahadyt, but that they expressed also practices, ideas and notions. Traditions, from an epistemological point of view, have goals, methods and specific language. (cf. Laudan, L., Progress and its Problems: Towards a Theory of Scientific Growth, Berkeley: California University Press, 1977; Laudan, L., Science and Values, California: University of California Press, 1984).

39. [13 vi, p. 518].

40. [26, p. 1]. Cf. also, Nuesner's [77] translation, p. 3.

41. [16 i, p. 219].

42. [26, p. 46]. Cf. also Goldin's [39] trans. P. 62.

43. Ibn Manzwr tells us that 'princes were called salātyn (the plural of sulțān) since rights and evidences are established by them,' [59 xiv, p.243] which means that that meaning of the term sulțān as a king or prince was a later development. 44. Ibn Manzwor tells us on the authority of āl-Layt that "āl-sulțān is king's power" [ibid.].

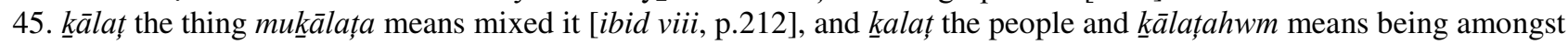
them, and kalyt of the people means their tapster and the one who sits and stay amongst them [ibid., 215].

46. See the next subsection, item n. 2.

47. The first scholar to note the relationship between Abw āl-Jalad and Ibn 'Abbās was I. Goldziher in his Die Richtungen der islamischen Koranauslegung, Leiden, 1952, p.66. However, Abw āl-Jalad was reported to have been 'a reader to the Torah books and what is relating to it / صاحب كتب التوراة ونحو ها ' the same report continues about Abw 'Imrān āl-Jawny's reciting on Abw āl-Jalad's authority by saying: 'recited on his authority [Abw āl-Jalad] Qatādah, Abw 'Imrān āl-Jawny and Ward' [12 ii, 2275]. And for his cooperation with Ibn 'Abbās in interpreting the Qur'ān by Jewish tradition and their correspondences, see [19 $i$ : 434; 723].

48. He recited on the authority of Sa'yd b. Jubayr, 'Ațā' b. Abw Rabāḥ, 'Ikrima, Kurayb, and Mujāhid [10 xi, 2467], all of them belong to Ibn 'Abbās' school.

49. In Ibn Sa'd [61 v, pp. 88-89] it is reported on the authority of Sulaymān b. āl-Raby' that some people from Basra to have requested from him some advice due to he 'had read the first book / وقد قرأت الكتاب الأول، i.e. the Torah. Also, the prophet said to him explaining a dream that he ['Amr] had seen it: 'if you lived you would read the two books: the Torah and the Qur'ān'. Thus, he was reading them [55 xxxi, p.255].

50. Ka'b said to 'Amr after the former asked him a question and the later answered to it 'this is written in the Torah as you said / إنها لمكتوبة فى التور اة كما قلت ' [ibid. xxxi, p. 264]. 
51. On the authority of 'Ikrima (one of Ibn 'Abbās' disciples) that he heard 'Abdallāh b. 'Amr says that 'Ibn 'Abbās is the best one in knowing the past and explaining the revelation.... 'Ikrima said, I told Ibn 'Abbās his speech, then Ibn 'Abbās said he had knowledge / ابن عباس أعلمنا بما مضى، و أفقهنا فيما نزل... قال عكرمة: فأخبرت ابن عباس بقوله فقال: إن عنده لعلماً. xxxi, p. 263].

52. We are told, on the authority of 'Amr b. Qays that 'Abdallāh b. 'Amr said 'it is a sign of the doomsday... that Mitnā (Mišnah) is being read among people but nobody interprets it, then he was asked what Mitna is? He replied it is what من أشر اط الساعة... أن تقرأ المثناة فى القوم ليس فيهم أحد يعبر ها قيل له: ما المثناة؟ قال: ما كتب سوى / was written but other than God's book 'كتاب اله ' [ibid. xlvi, p. 313].It should be noted here that that the speech of 'Abdallāh b. 'Amr has another wording which can contradict the above one. Thus, in [18 xiii, H14559] we have on the authority of 'Amr b. Qays, on the authority of 'Abdallāh b. 'Amr also, but on the mouth of the prophet that 'it is a sign of the doomsday ... that the Mitnā is being read among people / من أشر اط الساعة ... يُقر أ فى القوم المثناة.' This means, on the contrary of Ibn 'Asākir's text, that reading the Mitnā itself is a sign of the doomsday not the non-explaining it. But this second wording is not possible because of 'Abdallāh b. 'Amr's respecting of Jewish culture (There is another wording close to the second one in [3 vii, H4834]).

53. 'Moses...received the Torah at Sinai [ARNA, Goldin's [39] trans., ch. i, p. 3] ... Joshua took over from Moses [ibid., p.4] ... The Elders took over from Joshua [ibid.] ... The Judges took over from the Elders [ibid.] ... The Prophets took over from the judges [ibid.] ...Haggai, Zechariah, ad Malachi took over from the Prophets. The Men of the Great Assembly took over from Haggai, Zechariah, and Malachi (ibid.) ... Antigonus of Soko took over from Simeon the righteous [ibid., ch.5, p. 39] ...etc. Finally, Rabban Johanan ben Zakkai took over from Hillel and Shammai' [ibid., ch. 14 , p. 74].

54. The relationship between Abw-āl-Dardā' and Ka‘b was so closed that the former's wife was telling from Ka‘b [51 $i$, 343], she also called Ka‘b as Abw-āl-Dardā's brother [22 iii, p. 493]. Also, Abw āl-Dardā' said about Ka‘b that he 'had great knowledge' [61 ix, p. 449].

55. For a biography which shows how 'Atā' was one of the adherents of Ibn 'Abbās' tradition and influenced with Jewish traditions see [10 $x x, 3941]$.

56. [55 l, pp. 164-65].

57. 'Then we bequeathed the book to whom we chose from our worshippers / ثم أورثنا الكتاب الذين اصطفينا من عبادنا $Q .35: 32$. 58. Concerning interpretation in ARNA by just mention the rules of interpretation without any details, see [Goldin's [39] trans., p. 74, and with citing RS, see: ibid., P. 154]. Concerning indicating to the importance of interpretation, see [ibid., p. 5, 91].

59. It should be noted that Abw āl-Dardā' also, one of the translation movement supporters said on the authority of Ibn لن تفقه القرآن كل الفقه حتى ترى للقرآن / Abw Qilāba 'you will not understand the Qur'ān entirely until you can see aspects for it 'وجواً [61 ii, p. 308].

60. Bravmann [31, p. 185] sees that 'certainly, the principles of $r a$ ' $y$ and 'ilm cannot be considered as having been suddenly introduced by 'Umar (or his immediate predecessors), rather it may be assumed that the Arab mind had been familiar with these principles in a considerably earlier period' (Italics are mine). But this is just an assumption, while our reconstruction is based on facts and parallel texts.

61. For a serious study about the jurisprudence of Ibn 'Abbās' students, see [71].

62. Hishām Ibn Yūswf the judge was one of āl-Šāfi'y's teachers in Yemen [37, p. 44].

63. 'He obtained (knowledge) from Ibn 'Abbās, Abw Hurayra... 'Abdallāh Ibn 'Amr... and Țāwws', 'The Abundance of his knowledge was from the scripts of the people of the book', 'he was a judge on Şan'ā' [22 iv, p. 545].

64. 'He memorized from ... Ibn 'Abbās', 'and he was buying books for his brother' [22 v, 311-12].

65. Most Islamic law scholars concentrated on the influence of Medina school of fiqh on āl-Shāfi'ī, or as Motzki puts it 'The proportion and the importance of Meccan fiqh in the work of āl-Šāfi'y has not yet been properly appreciated by research. Until now it has always been assumed that the decisive influence on āl-Šăfi'y emanated from Malik and Medinan jurisprudence. One of the reasons for this assessment is probably to be sought in the fact that almost nothing was known of Meccan fiqh' [71, p. 292]. In the present paper, I did not commit to this mistake. Instead, I concentrated on Medina's linguistics as it will be shown below. Moreover, I have to refer that ra' $y$ techniques was also prevailed in Medina (see for the nature of these techniques; [82, pp. 113-119] [98, pp. 145-182], which means (in addition of influence of 'Umar's translation movement on Medina scholars and transmission of $R S 1-3 ; 6$ rules to the Medina traditions) More influence of $R S$ on āl-Shāfi'‘’’’s informal logic.

66. I say that āl-Šāfi' $y$ borrowed only the term qiyās of the Iraqis grammarians not its content, that because there is a difference between the grammarians qiy $\bar{a} s$ and the jurists one, or as Versteegh explains: 'the qiyâs of the Arabic grammarians represents a totally different concept: it is a method to explain apparent deviations from the rules in certain phenomena by referring to their resemblance to other phenomena. The result is an increased regularity because the rules are applied to as many phenomena as possible. This kind of analogical reasoning is different from the concept of 'analogy' in Western linguistics, which serves as an instrument to explain irregularities by showing how they developed by interference from other phenomena' [95, p. 35]. And it is a known fact the borrowing of terms amongst sciences.

67. He is reported in many sources to have made a poem which started by saying 'Grammar is nothing but qiyās which is followed / إنما النحو قياس يُتبع '9 xiii, p. 355].

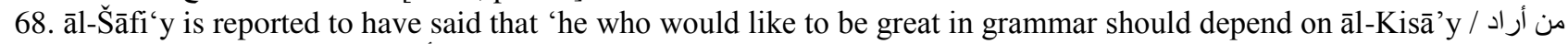
[أن يتبحر فى النحو فهو عبال على الكسائى '55 lx, 116-17]. 
69. This is reported by [3, p. 107 ff.]. In addition, āl-Šăfi‘y wrote many polemical essays against Iraqis jurists, for example; Kitāb āl-Radd 'ala Muhammad Ibn āl-Hasan, in [15 ix, pp. 85-170]. Cf. also [34, p. 182].

70. al-Šăfi‘y has been to Iraq twice, the first time for a trial in which he learnt from the Iraqis (around 796), and the second one for teaching (813) [34, p. 182].

71. There are here two problems/questions; (1) did Aristotle's On Rhetoric was translated before the end of the second century A.H., the time of āl-Šăfi' ‘y’s activities? (2) Did āl-Šāfi ‘y has knowledge of the Hellenistic tradition? Concerning the first question, most scholars who wrote on the ancient Arabic translation of Aristotle's On Rhetoric believed that it was translated about the end of the second century A.H. (for example, Badawi's [28] introduction to his publication of the translation, p. j; Lyons' [65] introduction for his edition, p.i, where he puts its date (p. vi) at 731). Only U.Vagelophl [94] believed that it was translated later at al-Kindy's (805-873) circle [ibid., pp.130; 165; 180] based mainly on terminology, but this is not acceptable, because the most important terms are not kindian, such as $\pi \alpha \rho \alpha \dot{\delta} \varepsilon \gamma \mu \alpha$

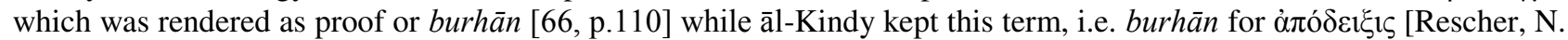
Studies in the History of Arabic Logic. University of Bitsburgh Press, 1963, p. 14]. Concerning the second question, we have in āl-Bayhaqy's book about āl-Šāfi‘y a report about āl-Šăfi‘'y, although says that āl-Šāfi‘y had read Aristotle's books in medicine [4 $i$, p. 133] which is absurd, but reflects his knowing of Aristotle.

72. Lowry sees that there are only four rules, or as he puts it: 'in any event, Šăfí'ī views the permissible forms of qiyās as three: the argumentum a fortiori, ma 'nā-based qiyās, and shabah-based qiyās,' [64, p. 154], again the argumentum a fortiori divides into two; 'the argumentum a maiore ad minus and a minore ad maius,' [ibid., p. 153]. This is also Hallaq's view [45, pp. 23, 29]. But, in fact, the argumentum a fortiori has three forms not two as we shall show.

73. If it is permissible for you to eat three apples that does not mean it is permissible for you to eat more.

74. We may connect this with Schacht's observation about the religious and ethical nature of Islamic law and jurisprudence $[82, \mathrm{p} . \mathrm{v}]$.

75. What is between the brackets is TAR L's reading.

76. Cf. Khadduri's [62, p. 79] trans. '[Analogy's] conformity [to precedent] should be based on two conditions.'

77. Khadurri translates ' $m a$ ' $n \bar{a}$ ' here as meaning not reason (Risāla M, p. 290)

78. Lowry also criticizes Hallaq but because the ratio legis is a lawful technique for resolving ambiguities while 'in Islamic law, the immediate purpose of the $m a$ ' $n \bar{a} /{ }^{\prime} i l l a \bar{a}$ is not to resolve ambiguities in the law, but to extend a statute of known meaning to a case of first impression.' [64, pp. 150 - 151, n.132].

79. Lowry criticized Hallaq for his confusing the a simili with Sh.5 as 'the argumentum a simili thus seems closer to Šăfi'î's concept of ma 'nā-based qiyās [Sh.4]' [64, p. 152, n. 133]. Thus, Lowry seems to have fallen at the same mistake by regarding āl-Šăfi'‘i’s aim was the purpose not meaning.

80. The Syriac translator rendered the Greek word $\pi$ í $\tau \imath \varsigma$ as tașdyq. For more details, see [66, p. 115].

81. We should note here that the Syriac translator(s) rendered the Greek word $\dot{\alpha} \pi$ ó $\delta \varepsilon 1 \xi 1 \zeta /$ demonstration by the Arabic word tatbyt or tatabut. Cf. [66, p. 21. And p. 173, for more details].

82. The Syriac translator rendered the Greek word غ̇ं $\alpha \gamma \omega \gamma \eta$ /induction as i'tibār. See for more details [66, pp. 58, 239].

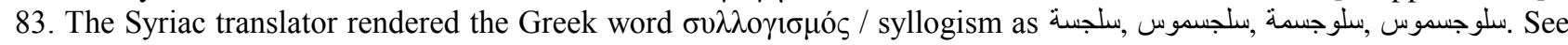
for more details [66, pp. 132, 213].

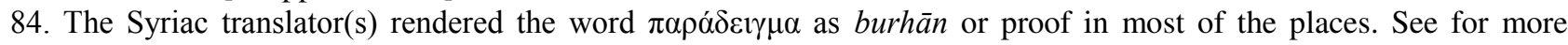
details [66, pp.110, 167].

85. The Syriac translator(s) rendered the Greek word ह̇v $\theta \dot{v} \mu \eta \mu \alpha$ as tafkyr. See for more details [66, pp.56, 259].

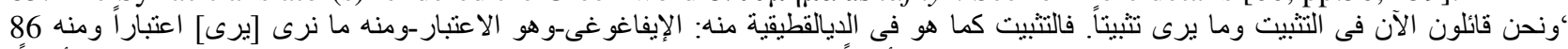

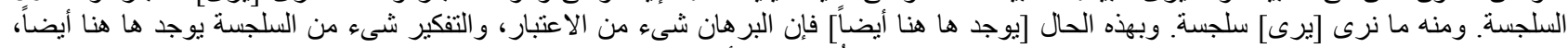

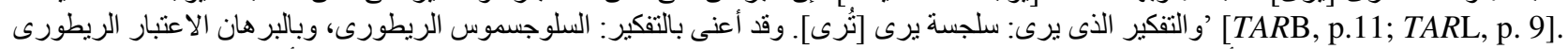

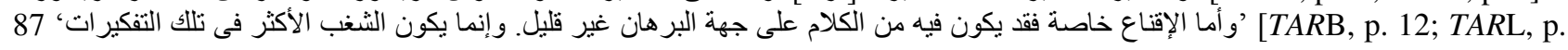
10]

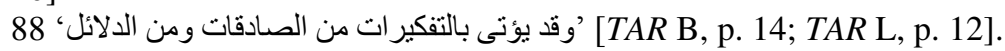

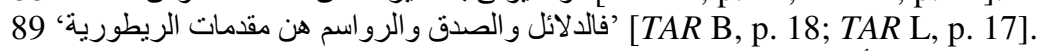

90. Also, he says at [TAR B, p. 178; TAR L, p. 169] فأما أن يكون كل شىء من الرسوم غير ذي سلوجسموس فقد تنين لنا فى أنالوطيقى, without any clarification.

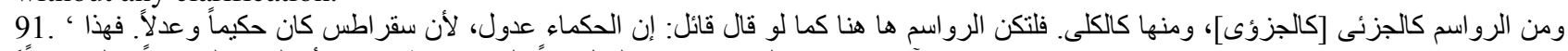
[الآن رسم، وهو له إن كان هذا القول حقاً وليس باضطر لارى، لأنه ليس سلوجسماً [سلوجسمياً]

92. What are between < and > is Badawi's additions, and it seems to be reasonable. Lyons edited the text as following: 'ونحو آخر من قبل العلامة، فان هذا ايضاً بلا سلجسة...او لو قال قائل ان ديانوسوس * * لانه شرير، فهذا غبر ذي سلوجسموس* * شرير، [TAR L, p. 164]. What are between two asterisks is lacunae in the original ms.

93. The apodeixis syllogism is inferred from [24, 1357a: 29-30].

94. [TAR B, pp. 6-7; 11; 15].

95. The word $\dot{\alpha} \pi$ ó $\delta \varepsilon \xi \xi 1 \zeta$ or demonstration even was rendered as tathbyt as we said before.

96. Demonstration does not aim to persuasion at Aristotle.

97. My translation seems to be incomprehensible, that because the Arabic passage is also so. I tried to render this incomprehensibility in the English translation too. It should be noted that I did not translate bi al-äktar as at the most part, as it would be expected. The reason will be clear at the next few pages.

98. Khdduri's note n. 1, p. 67 in: Risāla M. 
99. For God's Bayān see [Risāla K: 53; 54], for the messenger's Bayān see [Risāla K 58]. Cf. also, [64, p. 23 ff]. 100. ، 1Bayān] consists of what God commanded his creatures to seek through 'ijtihād' [Risāla K: 59] [Risāla M, p. 68]. Cf. [64, p. 23 ff].

101. Bayān is including also (1) linguistic manners and styles [Risāla K: 174-176]; cf. [TAR's third treatise on Style],

(2) RS: 4-5 or the general/ خاص/Risāla K: 173, and passim].

102. Cf. Also, [15 ix, p. 77], where he provides an example for a blind that needs for demonstration.

103. Cf. Also, [ibid., pp. 8; 11; 19-20; 32; 33; 34; 35].

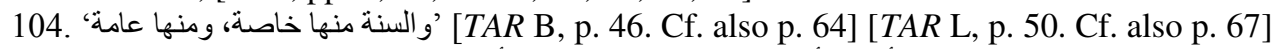

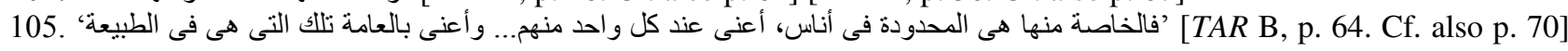

[TAR L, p. 67. Cf. also p.73].

106. This is the concept of sunna in TAR. But it has other ramifications which will seem to be in opposition to alŠăfi'y's concept. For TA the general sunna is not written, while the particular sunna is written (some of it in reality) [TAR B, p. 46; 64] [TAR L, p. 50; 67]. This seems to be in opposition to āl-Šāfi'y's concept, because, for him, the Qur'ān is the book (written) in which there are 'بنص / النصوصة الفرائض / the texted duties' [Risāla K: 97] while the prophet's sunna is his practice which is ' بلا نص كتاب / without a texted book' [Risāla K: 100]. But if we contemplate a little, we shall discover that there is no opposition, Because TA's non-written general sunna expresses absolute laws like the Qur'ān's: 'هو الثئ الذى يزكيه [يزكنه] الكل بالطباع/it is the thing which everyone approves [appealed to] it naturally' [TAR B, p. 64; TAR L, p.67], while his particular sunna expresses laws which should not contradict the general one ' المكتوبة مضادة للأمر ، قد ينبغى أن نستعمل السنة العامة the general one' [TAR B, p. 71] [TAR L, p.73], this is just as the prophet's sunna in āl-Šăfi' 'y's concept for it [Risāla K: 307]. In addition, the prophet's sunna, for āl-Šăfi'y, is Ahadyth or the prophet's fixed speech, i.e. written. (It is known thanks to Schacht [81, p. 145] that āl-Šăfi'y triumphed for Ăhadyt movement in his time)

107. See the above note.

108. [Ms.23a-23b]. It must be noted here the different reading of Lyons where he reads: “ 'حكيماً ما هو أحداً / some wise man who is unique, as: 'حكياً ماهر اً جداً/a very clever wise man' [TAR L, 75b: 22-23, p. 74.]. However, this does not effect in the significance of the sentence in general, i.e. it should be there some wise man. But on my reading which accords to the Arabic Organon manuscript, this wise man should be only one man, a unique one. It should be noted also Badawi's different reading for another word in that sentence. Thus, he reads: 'يرذل / be getting bad,' as: ‘رد / comes to you' [TAR B, p.72]. It should be noted also the great difference in meaning between the [Ms.23a-23b] and the Aristotelian text [1375b: 23-24]: 'And [one should say] that to seek to be wiser than the laws is the very thing that is forbidden in those laws that are praised'.

109. This happens during his arguing against 'istihsān and Iraqi school, thus he says: ' فإن قلتم: لأنهم لا علم لهم بالأصول if you say because they have no knowledge of elements/usūl' [15ix, p. 74] and his intention by these elements is the Qur'ann and sunna as it is shown by the next paragraphs. He also calls the knowledge of the Qur'ān and sunna ' على لأصول / science of the elements' [15 ix, p. 77]. Cf. Also, [84, p. 60]. However, some scholars [35, pp. 55-60] [33, p. 78] [45, p. 22] supposed without any textual justification that āl-Šăfi'y had four elements (or sources). Lowry [63] refused to consider that āl-Šăfi 'y had any theory about elements or sources [ibid., pp. 24, 50], because, from his point of view, whenever āl-Šăfi'y speaks about elements or sources, then his talking either messy or out of context [ibid., pp. 32-33]. Lowry arrived to this conclusion as a result of his gathering of lists of āl-Šăfi 'y's sentences about elements [ibid., pp. 31- 32]. But most of what he gathered are not sentences about elements so far as Lowry's believing so. Most of the sentences in Lowry's lists do not contain the word usūl/elements (for example, [Risāla K: 397; 881; 1101]. Thus, Lowry also like the other mentioned scholars does not have textual evidence for his claim.

110. For example: ' فلا يجوز أن يقال لقول: فرضٌ إلا لكتاب الله، ثم سنة رسوله / So it is not permissible to regard anything as a duty save that set forth in the Qur'ān and sunna of His Apostle' [Risāla M, p. 112]. See also [Risāla K, 266; 281; 293, and Passim].

111. Schacht [48, pp.17-19]. For a more detailed analysis and meanings of the term sunna, see [23, pp. 259-282].

112. 'And He [God] said: God has sent down to thee the Book and the Wisdom, and has taught thee what thou did not know before; the bounty of God towards thee is ever great [Q. IV, 113]... So God mentioned His Book - which is the Qur'ān - and Wisdom, and I have heard that those who are learned in the Qur'a $\bar{n}$ - whom I approve - hold that wisdom in the sunna of the Apostle of God' [Risāla M, p. 111; Risāla K: 250 252].

113. For the primary meaning of the term ijtihād, see [31, pp. 188-194]. And for its development [45, pp. 19-20].

114. āl-Šāfi'y says about the a fortiori: 'فأقوى القياس / and the strongest qiyās' [Risāla K: 1483].

115. [TAR B, pp. 11, 13-14] [TAR L, pp. 10,12], their counterparts passages in On Rhetoric are [24, 1356b 15-16; 1357a 31-33] respectively.

116. It is interesting that neither Hallaq [43] [45] nor Lowry [64, pp. 32-3; 147 ff.] recognized inferring by sign at ālŠăfi'y. However, Lowry identified it as 'in the nature of estimation based on incomplete information, driven by necessity, and evaluated in terms of purely pragmatic consideration' [64, p. 147]. But as I shall show that this is not correct.

117. [82, pp. 99-100]. Also, [64, p.153, n.138]. Our result is confirmed also by H. Motzki [70] statistical research about the role of non- Arabs converts in the Islamic formative scholarship. According to this statistical work, their role was weak in comparison to the native Arabs from the Arabian Peninsula. 
118. For the influence of Hellenistic rhetoric on the Jewish or Hebraic informal logic, see: Daube, D., 'Rabbinic methods of Interpretation and Hellenistic Rhetoric,' in: Hebrew Union College Annual, 22, 1949, pp. $239-264$.

119. [22 ii, p.448].

120. For Ka'b's son and their knowledge of the ancient books, see [61 ix, p. 455].

121. The other misunderstanding of Aristotle because of translation in philosophy is the attribution of theology of Aristotle (in fact, extracts from the Enneads of Plotinus) to Aristotle. For more details, see: Rowson, E.K., 'The Theology of Aristotle and Some Other Pseudo-Aristotelian Texts Reconsidered,' in: Journal of the American Oriental Society, 112, 1992, pp. 478-484. 